\title{
LA INFLUENCIA DEL CONSTITUCIONALISMO FRANCÉS EN LA FASE DE REAFIRMACIÓN CONSTITUCIONAL ESPAÑOLA $(1837-1845)^{1}$
}

\author{
POR \\ JOSÉ MANUEL VERA SANTOS \\ Profesor Titular de Derecho Constitucional. \\ Universidad Rey Juan Carlos
}

\section{INTRODUCCIÓN}

Como tuvimos ocasión de razonar en un artículo anterior publicado en esta misma revista ${ }^{2}$ y después de haber estudiado la influencia francesa en nuestro primer constitucionalismo, continuamos el estudio de dicha influencia en los textos españoles de 1837 y 1845, además de en los numerosos intentos de reforma que éste último sufriera, dentro de un periodo que ha sido calificado como de "reafirmación constitucional $\varkappa^{3}$. Y todo ello debido a que, como indicamos, la presencia doc-

1 Este artículo ha sido elaborado dentro del Proyecto de Investigación del Plan Nacional de Investigación Científica, Desarrollo e Innovación Tecnológica "La influencia del constitucionalismo europeo en la historia constitucional española» (BHA 2000-0406), cuyo investigador principal ha sido el Profesor González-Trevijano.

2 Vid. Vera Santos, J. M. "La influencia del constitucionalismo francés en la fase de iniciación constitucional española», en Revista de Derecho Político n. ${ }^{\circ} 66$, 2006, págs. 121-179.

3 DE ESTEBAN, J. (Las Constituciones de España. Madrid: CEPC, 1997, págs. 24-41), en concreto, respecto a esta fase de reafirmación constitucional, vid. págs. 28 a 30. 
trinal y normativo-constitucional de nuestro vecino país, resulta especialmente relevante en estos primeros pasos de nuestro incipiente constitucionalismo.

Igualmente, para dotar de continuidad a ambos artículos, seguimos incidiendo principalmente en el aspecto institucional, partiendo de los textos españoles para, posteriormente, comparar la influencia en los mismos del constitucionalismo francés. Como en el anterior estudio, en éste aludimos también, en primer lugar, al articulado constitucional, testando, a partir del mismo, las aportaciones doctrinales. De ahí la importancia de acudir a los textos constitucionales tanto nacionales como franceses, consulta de éstos últimos textos que seguimos remitiendo a Las Constituciones de Francia (Valencia, Tirant lo Blanc, 2004), debido al sencillo cotejo tanto de las Constituciones - en su idioma original o traducidas al castellano- como al estudio previo de éstas que en el volumen se contiene.

Tanto respecto a la Constitución de 1837 como a la de 1845, metodológicamente aludimos, en primer término, a una introducción histórico-política y referida a las más destacables características de la regulación dogmática que cada Constitución aporta. Posteriormente nos referimos a la organización institucional. Parte orgánica y dogmática que comparamos no sólo con la normativa constitucional gala, sino también con los antecedentes patrios, en un ejercicio complejo pero, consideramos, necesario, para una mejor y más global comprensión de la evolución de la influencia francesa en nuestros textos constitucionales. $Y$ es que, si el constitucionalismo francés influye en la Constitución de 1812 o en el Estatuto Real de 1834, creemos necesario observar también como los textos españoles previos pueden también influir, o no, en las Constituciones de 1837 y 1845. Culminamos el estudio con las referencias a los intentos de reforma sufridos por la Constitución de 1845, destacando sobre las demás - por motivos históricos, políticos y constitucionales-, los textos de Bravo Murillo en 1852 y la "non nata» de 1856, siendo ésta última un intento de reafirmar el proyecto político liberal de 1837, frente al resto de proyectos de reforma, que lo eran respecto al texto moderantista de 1845, Constituciones de referencia con las que establecemos la pertinente comparación. Sin olvidar, eso sí, que

Alude DE ESTEBAN a las siguientes fases del constitucionalismo español: iniciación constitucional (1808/1812-1834), reafirmación constitucional (1837 y 1845, incluidos los textos de reforma de éste último); fase revolucionaria (Constitución de 1869 y proyecto republicano); fase de la restauración (primero monárquica, con la Constitución de 1876, y luego republicana, con el texto de 1931), hasta llegar, previa fase autoritaria, a la de reinstauración monárquica. 
ambas Constituciones conforman un modelo constitucional común, que, como veremos, podemos calificar como de tendencia moderada, de liberalismo doctrinario.

A este periodo de "consolidación democrática»" ${ }^{4}$ nos vamos pues a referir, bien que sin olvidar que esta consolidación distó mucho de impedir un continuo vaivén de proyectos, textos, intentos de reformas y regímenes de hecho que la desvirtuaron en la práctica, por lo que esta teórica reafirmación constitucional no pudo poner fin a nuestra tormentosa, a veces - demasiadas veces-cainita, existencia políticoconstitucional ${ }^{5}$.

En estos actuales tiempos de intentos y más intentos de reforma constitucional, quizás no suficientemente meditados, y en cualquier caso, no consensuados, que la historia nos sirva, también hoy, de ejemplo; que aprendamos de ella y que recordemos-sí, también hoy-, la responsabilidad de todos para con todos y para con España, logrando que esa ureafirmación constitucional" se produzca de común acuerdo y que, por lo mismo, no comencemos un viaje sin retorno en el que la Constitución no suponga sino un instrumento más en manos de un siempre cambiante poder político que haga volver nuestros ojos - constitucional e históricamente tan cansados-, hacia aquella machadiana y goyesca España, dividida y enfrentada, que creíamos olvidada.

\section{LA CONSTITUCIÓN DE LA MONARQUÍA ESPAÑOLA DE 18 DE JUNIO DE 1837}

\subsection{Introducción. Parte dogmática}

La Reina Gobernadora disuelve el Estamento de Procuradores el día 22 de mayo de 1836 ante el voto de censura del que fue objeto Istúriz ${ }^{6}$.

${ }^{4}$ Así lo califica Pérez-Prendes y Muñoz-Arraco, J. M. "Sobre Constituciones y revoluciones burguesas", en Revista de Derecho Político, n. ${ }^{\circ} 20$, 1983-1984, págs. 7-13 (7).

5 Vid. resumen de los rasgos definidores del constitucionalismo español en VERA SANTOS ("La influencia del constitucionalismo francés...», o. c., págs. 123-131), siguiendo en este punto a J. DE ESTEBAN en su Tratado de Derecho Constitucional. Madrid: Facultad de Derecho de la Universidad Complutense de Madrid, 1998, págs. 14 y siguientes. Brillante síntesis doctrinal también en el prólogo a GARCíA FERNÁNDEZ, F. J., EsPíN TEMPLADO, E. y DE ESTEBAN, J. (dir). Esquemas del constitucionalismo español. Madrid: Facultad de Derecho de la Universidad Complutense de Madrid, 1976, págs. 13-38.

${ }^{6}$ Vid. Vera SANTOS ("La influencia del constitucionalismo francés ...», o. c., págs. 163-164, nota 116). 
La inestabilidad política se une a diversos levantamientos y agitaciones sociales que culminan con el motín de La Granja el 12 de agosto de este año, obligando a María Cristina a restablecer la Constitución gaditana hasta que "la Nación en Cortes, manifieste expresamente su voluntad, o de otra Constitución conforme a las necesidades de la misma ${ }^{7}$. Calatrava es Ilamado al Gobierno y se convocan Cortes constituyentes $^{8}$ a celebrar en octubre de ese mismo año. Al mes siguiente se designó una Comisión que presidía Argüelles y cuyo secretario era Olózaga ${ }^{9}$, elaborando unas bases para reformar la Constitución

7 El texto citado está tomado del «Real Decreto mandando S. M. publicar la Constitución" fechado el 13 de agosto (SEVILLA ANDRÉs, D. Constituciones y otras leyes y proyectos políticos de España 1808-1969. Madrid: Editora Nacional, 1969, 2 vols, vol. I, pág. 301). Respecto al motín de La Granja se destaca que fue uuno de los más vergonzosos episodios del constitucionalismo español. Los emisarios de las sociedades secretas sobornaron y emborracharon a la guarnición del sitio real, que capitaneada por los sargentos invadió el Palacio y obligó a la Regente a proclamar la Constitución de 1812" (SÁNCHEZ AgESTA, L. Historia del constitucionalismo español. Madrid: Instituto de Estudios Políticos, 1974, pág. 264). Respecto a la crisis del régimen del primer liberalismo vid. NúÑez Rivero, C. y MARTínez SegarRA, R. M. Historia constitucional de España. Madrid: Universitas, 2002, págs. 105-107 y 111-113, con un resumen histórico clarificador, que no olvida la importante tarea que desarrollo Mendizábal con la aplicación de la desamortización eclesiástica, (Ley de 29 de julio de 1837), tan importante para derrotar al antiguo régimen y para potenciar a la burguesía, que apoyara la causa liberal, al igual que una nobleza que mantiene y acrecienta su fortuna.

8 El profesor FERnÁNDEZ SEgAdo en su conocida obra Las Constituciones históricas españolas. (Madrid: Civitas, 1986, págs. 172-182), considera que son Cortes constituyentes, a pesar de que en el Preámbulo del propio texto constitucional se reseñe que es una revisión de la Constitución de 1812, ya que tampoco se siguió el procedimiento de reforma que se establecía en los artículos 375 a 384 del texto gaditano. Incide en esta idea el autor en su artículo «Pragmatismo jurídico y concertación política: dos ideas-clave en la obra de los constituyentes de 1837", en Revista de Derecho Político, n. ${ }^{\circ}$ 20, 1983-1984, págs. 33-65 (38-41). De idéntica opinión TomÁs VILLAROYA (Breve historia del constitucionalismo español. Madrid: Centro de Estudios Constitucionales, 1981 (ed. 1987), pág. 49), al distinguir los aspectos formales proclamados de la realidad alcanzada: extensión dispar, instituciones de gobierno diferentes y la aprobación de la misma por un procedimiento no recogido en el texto de Cádiz. Idéntico sentir en Pérez-Prendes Muñoz ArRAco (o. c., pág. 11), aludiendo al "desvío" que significa el texto de 1837 respecto al de la Constitución de 1812. Cabe indicar que las elecciones celebradas el 2 de octubre de 1836 y que dan origen a las Cortes constituyentes, se realizan según un sistema de sufragio universal indirecto que estableció el Real Decreto de 21 de agosto.

9 De Olózaga dice TOMÁs VilLAROYA (o. c., pág. 48), que es un «joven valor de un nuevo progresismo que miraba más a las constituciones europeas de su tiempo que al viejo texto gaditano", para más adelante indicar la influencia del texto francés de 
de 1812, bases que son leídas en las Cortes el 30 de noviembre y que tendían a acrecentar los poderes del Monarca, reducir las materias constitucionales, optar por una elección directa de los diputados y establecer un sistema bicameral ${ }^{10}$. Estas bases son aprobadas en diciembre y la misma Comisión elabora un proyecto que se discute en las Cortes hasta el mes de mayo de 1837, aceptando María Cristina, en nombre de su hija Isabel, el nuevo texto el 18 de junio, logrando la consecución de una nueva Norma Fundamental ${ }^{11}$ transaccional $^{12}$, que pudiera suponer un punto intermedio entre las posiciones, tanto de progresistas

1830 y del belga de 1831, influencias que también reconocen TORRES DEL MORAL, (Constitucionalismo histórico español. Madrid: Átomo, 1986 (ed. 1991) pág. 66), Sánchez Agesta (o. c., pág. 267), Fernández Segado (o. c., pág. 180) o Merino Merchan (Regímenes históricos españoles. Madrid: Tecnos, 1988, pág. 79), así como ColoMER VIADEL (El sistema político de la Constitución española de 1837. Madrid: Congreso de los Diputados, 1989, págs. 653-656, con citas de legisladores como Pascual, Fermín Caballero o el propio Presidente Calatrava). De Argüelles, poco más que señalar su presencia en estos primeros tiempos constitucionales españoles, en este caso, adoptando posiciones bicameralistas, frente a sus anteriores pensamientos monocamerales.

10 Vid. texto en SevilLa AndRÉs (o. c., págs. 307-316). Excelente estudio sobre las mismas, con abundante presencia de citas de autoridad y de intervenciones de los parlamentarios recogidas en los Diarios de Sesiones, que ponen de manifiesto la importancia de estas bases, es el de FERNÁNDEZ SEGADO, F. "Las bases vertebradoras de la Constitución de 1837", en Hispania, 1987, págs. 679-744. Especialmente relevantes a estos efectos las páginas 702 a 744 .

${ }^{11}$ Diferente pues a la de 1812, por lo que no podemos hablar de reforma de ésta sino de modelo constitucional distinto. Así TORRES DEL MORAL (o. c., pág. 66) alude a "un edificio constitucional de nueva planta, en el que junto al precedente gaditano se detecta la influencia de las Constituciones francesa de 1830 y belga de 1831 ». También lo destaca Fernández Segado («Pragmatismo jurídico ...», o. c., págs. 41-49), siguiendo a Tomás Villarroya y a la mejor doctrina.

12 De "transaccional» la califica VARela SuAnzes-CARPegna, J. ("La Constitución española de 1837: una Constitución transaccional», en Revista de Derecho Político, n. ${ }^{\circ} 20,1983-1984$, págs. 95-106), diferenciando esencialmente tres aspectos en los que observamos dicha transacción: "la amalgama de principios, unos progresistas y otros moderados" (pág. 95) que, en segundo término, "se consignaron sensiblemente atenuados, en una deliberada búsqueda de conciliación doctrinal (lo ejemplifica el autor en la reforma constitucional, «mixtura de soberanía nacional y flexibilidad", algo que el autor califica (pág. 96) de "incoherente»); en tercer lugar alude al "abanico de posibilidades que esta Constitución permitía, para que, sin salirse de lo constitucionalmente lícito, se diseñasen diversos órdenes políticos fundamentales" (pág. 97). De ahí que este autor califique la Constitución del 37 como "simbiótica, sincrética y elástica» (pág. 97). Como colofón, indica que la aprobación de la Constitución de 1845, de clara tendencia moderada, rompió con esta característica.

(C) UNED. Revista de Derecho Político 
como de moderados ${ }^{13}$ y en la que "los adelantos del siglo" y los ejemplos foráneos son observados con minuciosidad ${ }^{14}$.

La Constitución de 1837 se caracteriza formalmente por ser de extensión intermedia (setenta y siete artículos más dos adicionales, divididos en trece títulos, muy lejos, por tanto, del modelo doceañista con sus trescientos ochenta y cuatro artículos, tal y como pretendía la propia Comisión y las bases aprobadas) ${ }^{15}$, completo materialmente

${ }^{13}$ Así, por ejemplo, Sole Tura, J. y AJA, E. Constituciones y periodos constituyentes en España. 1808-1936. Madrid: Siglo XXI, 1977, pág. 33. También incide en este aspecto TOMÁs FONT DE LA MORA, M. A. en «La preparación de la Constitución de 1845». Revista de Estudios Políticos. 1991, n. ${ }^{\circ}$ 73, págs. 229-243 (pág. 229). «(...) Instrumento que debía actuar siempre en forma centrípeta, esto es, como elemento generador de unión, como un verdadero aglutinante social», (...) «la Constitución del 37 va a venir insuflada por un nuevo espíritu, tamizado de un sentido conciliador (...) escribe FERNÁNDEZ SEGADO («Pragmatismo jurídico...», o. c., págs. 50 y 53), aludiendo a las propias palabras de los constituyentes.

14 Vid. FeRnÁndez Segado "Pragmatismo jurídico...», o. c. pág. 49. Insistimos en esta idea porque, no lo olvidemos, este estudio trata sobre la influencia foránea, en concreto de la francesa, en los textos de 1837 y 1845. El propio autor citado, en otro de sus artículos, ("Las bases vertebradoras...", o. c. pág. 711-712), incide en esta cuestión, con citas de Argüelles y Pascual -este último denostando la influencia de la Carta francesa de 1830-, defendiendo un "deslumbramiento por el derecho de otros países, que se detecta con claridad en los Diarios de Sesiones, en los que encontramos multitud de referencias a preceptos e instituciones de otros ordenamientos, que se citan desde luego como argumentos de autoridad (...), [que] responde a lo que podríamos considerar como un intento de acomodo de la obra constitucional a lo que por aquel entonces se consideraba lo moderno, a lo que se entendía como el espíritu del siglo». Opiniones que destacan las presiones internacionales exteriores para conformar un texto moderantista y transaccional, las de $\mathrm{VA}_{\mathrm{A}}$ Rela SuANzes-Carpegna ("La Constitución....", o. c., págs. 97-100) o Torres del Moral (o. c., págs. 81-82). Tanto los unos como los otros no ponen en duda la influencia, con presiones políticas o sin ellas, de los textos extranjeros $y$, destacando entre ellos, la Carta francesa de 1830.

${ }^{15}$ Vid. la tramitación de la Constitución de 1837 hasta el juramento regio en GARCía AtANCE, M. V. "Crónica parlamentaria de la Constitución de 1837», en Revista de Derecho Político, n. ${ }^{\circ} 20,1983-1984$, págs. 171-183. De setenta artículos consta la Carta de 1830 francesa, texto de influencia decisiva en nuestra Constitución de 1837 y al que nos referiremos en numerosas ocasiones. Respecto a la Carta de 1814, precedente del texto de 1830, nos remitimos a lo ya expresado en VERA SANTOS ( "La influencia del constitucionalismo francés...», o. c., págs. 165-166, nota 120, y en Las Constituciones de Francia, Valencia: Tirant lo Blanch, 2004, págs. 294-299). El preámbulo de la Carta de agosto de 1830 indica que no es sino la puesta al día de la anterior de 1814, bien que la doctrina considera que "su espíritu es profundamente diferente", aludiendo a la nueva aparición del principio de soberanía nacional y al carácter pactado del texto constitucional (HAMON, F., TROPER, M. y BouRdeau, G. Droit 
hablando - por vez primera se sistematiza la parte dogmática, siguiendo los textos franceses de 1814 y 1830 y el proyecto patrio de Istúriz $^{16}$ - , aunque con continuas referencias al desarrollo legislativo posterior, lo que le dota de carácter elástico, políticamente permeable a posiciones políticas variadas ${ }^{17}$, siendo además sistemático y flexi-

Constitutionnel. Paris: LGDJ, 2001, pág. 328). Así, ha de destacarse cómo han cambiado determinadas cuestiones: se admite la bandera tricolor en lugar de la borbónica de la flor de lis; Luis Felipe no es Ilamado ni Felipe VII ni Luis XIX, para no entroncar con un pasado que se pretende superar (DeBbASCH, Ch., PONTIER, J-M., Bourdon, J. et RıCCl, J. Cl. Droit Constitutionnel et institutions politiques. Paris: Economica, 1990, págs. 444-445). Por su parte M. de GuILlENSCHMIDT (Histoire Constitutionnelle de la France depuis 1789. Paris: Economica, 2000, pág. 51) indica que la nueva Carta aporta muchas novedades en su apuesta por el liberalismo: la desaparición del carácter pactado de la misma; la religión católica no es la estatal, o la derogación del artículo 14 con la consecuente pérdida por el Monarca de regular mediante ordenanzas en caso de que fuese necesario para la seguridad del Estado, junto a la regulación por ley de los requisitos electorales. Muy gráficamente expresa García Pelayo en su Derecho constitucional comparado (Madrid: Alianza, 1991, pág. 479) que «(...) la Constitución que ahora se implanta mantiene todas las partes del anterior edificio constitucional, pero no deja a ninguna exactamente como estaba».

En fin, sus setenta artículos, en los que se observa una clara relación con los sesenta y siete del texto anterior, parten del reconocimiento previo de dos realidades como son el Rey y la Nación, sujetos que pactan entre ellos, llamando éste último al primero al Trono - tal y como se desprende también del propio preámbulo-, después de las jornadas revolucionarias de julio de ese año. De este pacto se deriva el carácter flexible del texto; una flexibilidad que se predica de los textos franceses y españoles de la época: Carta de 1814 y 1830, por un lado; de otro, el Estatuto Real de 1834 y Constituciones de 1837 y 1845. La parte dogmática reproduce casi literalmente la del texto de 1814. Como vemos, son las pautas básicas del moderantismo, del liberalismo doctrinario patrio, de nuestra teoría de la Constitución interna.

${ }^{16}$ «Es este proyecto - y no el Estatuto Real- lo que realmente se tiene en cuanta para preparar la nueva Constitución (...) es [el proyecto de Istúriz] el cañamazo donde se borda el texto de 1837" (BENEYTO, J. "Los derechos individuales", en Revista de Derecho Político, n. ${ }^{\circ} 20,1983-1984$, págs. 163-168 [163-164]).

17 Muy expresiva se nos presenta esta cita de TOMAS VILLARROYA (o. c., pág. 52): "en este sentido, Balmes advirtió que, en manos de Martínez de la Rosa llevaría a un sistema de gobierno parecido al Estatuto Real; en manos de Argüelles, a un sistema de gobierno parecido al de la Constitución de 1812. En suma: el texto de 1837 pudo haber puesto fin al periodo de convulsiones constitucionales iniciado con la guerra de la Independencia; las pasiones de los hombres y la turbulencia de los tiempos lo impidieron; y aquellas mismas leyes ordinarias que habrían debido permitir la variedad política en la estabilidad constitucional fueron, en alguna ocasión, el instrumento con el que se dinamitó un edificio que el buen sentido y la transacción habían construido para albergar a toda la familia liberal». Como elemento que se va a in- 
ble ${ }^{18}$, acogiendo como principios políticos los propios del doctrinarismo político: el reconocimiento previo de la Monarquía y de las Cortes, la soberanía compartida ${ }^{19}$ y la colaboración entre los poderes, fruto esta última del amenguamiento del liberalismo radical gadita-

corporar a nuestro "patrimonio constitucional» alude FERNÁNDEZ SEgADO («Pragmatismo jurídico..., o. c., págs. 53-54) a la remisión a leyes ordinarias para el desarrollo de determinadas instituciones (libertad de prensa, milicia nacional, sistema electoral, etc.), "como medio de solucionar, a priori, los hipotéticos conflictos (...) y todo ello con el fin último de lograr una Constitución estable y que pudiese actuar como fuerza centrípeta por mor de cuya acción la sociedad pudiese verse aglutinada, que no disgregada». Termina el autor resumiendo: "Estabilidad constitucional y concertación política se iban a convertir de esta manera para los constituyentes de 1836-1837 en los dos términos inexcusables de una ecuación que se iba a estimar imprescindible para el recto devenir de la nación". Bonitas palabras e intenciones, que, como aquél refrán español, quedaron embaldosando y engrosando el infierno - o, al menos, purgatorio- de nuestra azarosa vida constitucional.

18 Una flexibilidad que, como más adelante reiteramos, no es en absoluto congruente con un teórico principio de soberanía nacional, tal y como destaca TORRES DEL MORAL (o. c., pág. 67).

19 Torres del Moral (o. c., págs. 71-72) aboga porque en el texto de 1837 nos encontramos ante el principio de soberanía compartida, argumentándolo tanto en el carácter flexible que presenta el texto, en el sistema de sufragio no universal preconizado o en la propia fórmula de la promulgación de la Constitución (las Cortes decretan y sancionan y la Regente acepta). Por lo antes dicho se entiende que el catedrático de la UNED, en las páginas 67 a 71 aluda al liberalismo doctrinario, a la teoría de la "Constitución interna" en su triple vertiente (a su base eminentemente histórica para fundamentar las dos instituciones básicas - Corona y Cortes-; a que esta realidad se refleje por escrito en el texto constitucional, y que este reflejo aúne el poder social y político), aplicando la misma al texto liberal de 1837 . Y no le falta razón. MeRINo MeRCHÁn (o. c. pág. 79), alude a que, frente a lo que ocurría en 1812, cuando la soberanía nacional figuraba en el artículo tercero, ahora se desplaza al Preámbulo. Como además la potestad legislativa es compartida y la Constitución es flexible, la consecuencia fáctica es que la soberanía es también compartida. De idéntica opinión TOMÁs VILLLAROYA (o. c., pág. 51), vinculando esta soberanía compartida al hecho de que el texto de 1837 se presente flexible, sin procedimiento agravado de reforma. Defienden que la soberanía en 1837 se proclama como nacional, Colomer VIADEL, A. «El origen de la monarquía parlamentaria en España y el anteproyecto constitucional». Revista de Estudios Políticos, 1978. n. ${ }^{\circ} 3$, págs. 101121 , considera que, al igual que ocurre en el ejemplo belga de 1831, el Parlamento destaca frente a la Corona, como así se desprende del Preámbulo al constatar «que las Cortes Generales han decretado y sancionado, y Nos de conformidad aceptado ...". También lo recoge en su monografía citada (El sistema político ..., o. c., págs. 89-104). DE EsteBAN, J. (Las Constituciones de España. Madrid: Taurus, 1990, pág. 21) opta igualmente por la opinión de que este texto asume el principio de la soberanía nacional. Igualmente Pérez-Prendes Muñoz-ArRAco (o. c., pág. 12). También NúÑEz RIVero y Martínez SegarRa (o. c., págs. 119-120). 
no ${ }^{20}$ y de una visión más pragmática y jurídica de lo que debía significar una Constitución ${ }^{21}$.

Unos principios políticos que deben ser explicados. Así el principio de soberanía nacional del artículo 3 de la Constitución de Cádiz queda recogido en el Preámbulo constitucional de 1837, hecho que, unido al carácter flexible de la nueva Constitución, lleva a que en la práctica la Corona -dotada de iniciativa legislativa compartida con las Cámaras (art. 35) y de participación en el proceso legislativo-, sea partícipe de la misma, por lo que podemos hablar de soberanía compartida ${ }^{22}$; además se olvida el férreo régimen de separación de poderes del texto de $1812^{23}$, dando lugar a un sistema de colaboración entre los mismos, constitucionalizando con ello un régimen parlamentario que ya se había desarrollado en la práctica política durante la vigencia del Estatuto Real ${ }^{24}$. Así, el artículo 62 del texto de 1837 permite la compatibilidad del

20 «La Constitución de 1812 se restaurará por ser bandera de legitimidad y de libertad y porque permitía aunar los ánimos de quienes se habían levantado contra el Gobierno de Istúriz, pero, simultáneamente, se quería su revisión porque se entendía que sus preceptos habían quedado superados (...)" (FERNÁNDEZ SEGADO, "Pragmatismo jurídico ...", o. c., págs. 33-34). No hace falta mayor argumentación.

21 Seguimos nuevamente la opinión de FERnÁNDEZ SEGAdo (ibídem, págs. 5565), quién, aludiendo al magisterio de Sánchez Agesta, destaca cómo el positivismo y utilitarismo nacientes y presentes en la constituyente, hacen que su obra se separe de las tendencias moralizantes doceañistas, de la visión taumatúrgica, abogando por definir en la Constitución los aspectos y cuestiones "estrictamente necesarios» para una convivencia armónica y abierta a diferentes sensibilidades políticas, optando así por rechazar la constitucionalización de lo abstracto o reglamentista.

22 Vid. artículo 15 de la Carta francesa de 1830. Es notorio en este punto la influencia de una Carta francesa de 1830 que, aunque predica ser una mera reforma de la anterior, debido a la Revolución Gloriosa de julio, hace que la misma recoja "una convivencia entre la soberanía nacional y la Monarquía constitucional», algo que, "de facto" se puede calificar como soberanía compartida. Así se deduce, por ejemplo de HAMON, TROPER y BouRdEAU (o. c., pág. 328), autores que aluden al carácter pactado - que no otorgado-, del texto galo de 1830, frente a su antecesora de 1814. Vid. Vera Santos Las Constituciones..., o. c., págs. 295 y 299.

23 Vid. Vera SANTOS ("La influencia del constitucionalismo francés ...", o. c., pág. 151 , nota 74 y 155 y ss.)

${ }^{24}$ Ibídem, págs. 166-167. Es en este punto en el que podemos referirnos a la teoría de la Constitución interna, cuyos principios ya se observan en el texto español de 1834 y se perfeccionan en los textos de 1837 y 1845. Resumiendo a SÁNCHEZ AGESTA (o. c., págs. 363 y ss, sobre todo 375) esta teoría se basa en tres niveles y realizaciones: a) la "Constitución interna" o reconocimiento histórico y previo al texto escrito, de la existencia de dos principios preexistentes que dotan de contenido al ser político: el principio monárquico y las Cortes. Este primer estrato establece un sistema de Monarquía representativa; b) la "Constitución escrita», que debe asumir 
cargo de ministro y la condición de parlamentario, y el artículo 26 concedía al Rey la capacidad de disolución de la Cámara.

Ese pactismo entre liberales y moderados se observa no sólo en la cuestión de la soberanía, sino en que, frente a la sistematización -más liberal- de los derechos, la parte institucional asume postulados defendidos por la ideología moderada: bicameralismo (art. 13), veto regio (art. 39) o derecho de disolución (art. 26), son ejemplos de lo indicado ${ }^{25}$.

Se observa en este texto liberal por vez primera, la aparición en España de una declaración de derechos unificada y sistematizada, aunque ciertamente limitada e influenciada por un sentir individualista propio del primer liberalismo ${ }^{26}$. Así en el Titulo I vienen recogidas la libertad de imprenta - verdadero caballo de batalla de los liberales-, que no admite censura previa y que es calificada por jurados (art. 2) ${ }^{27}$; la unidad de jurisdicción y de códigos (art. 4) o la admisibilidad a los empleos públicos en igualdad de condiciones (art. 5). El artículo 11 por su parte reconoce el principio de la tolerancia religiosa, problema éste que llegará sin solución de continuidad hasta la República de $1931^{28}$.

los principios anteriores y que, partiendo de ellos, establece un sistema de soberanía compartida entre el Rey y las Cortes, dando lugar a lo que la doctrina califica como Monarquía constitucional; y c) "Constitución consuetudinaria" que, en desarrollo de las anteriores, permite, vía usos y costumbre, la existencia de un régimen parlamentario a partir de una colaboración entre los poderes legislativo y ejecutivo, siguiendo el modelo británico, tal y como ya intuyese Montesquieu.

${ }^{25}$ Vid. Fernández Segado (Las Constituciones históricas.... o. c., pág. 203), siguiendo a Sánchez Agesta.

${ }^{26}$ Por todos, Pérez-Prendes Muñóz-Arraco ( Sobre Constituciones ..." o. c., pág. 12). De un "enfoque pragmático-jurídico" en la parte dogmática, alejado de visiones taumatúrgicas doceañistas, abogando por el binomio reconocimiento del derecho y sanción por su incumplimiento, aderezado por el necesario desarrollo normativo de los mismos, habla FERnández SEgAdo («Pragmatismo jurídico...», o. c., págs. 62-63)

27 Destaca BeneYto (o. c., pág. 167) cómo se avanza desde el régimen gaditano (art. 371), pasando por el proyecto de Istúriz (que en su artículo 3 olvida el calificativo de "políticas" aplicado a las ideas cuya difusión es autorizada sin censura previa, abriendo así este derecho), hasta llegar a la regulación citada de 1837, bien que luego los Reglamentos de octubre de 1837 y junio de 1839 recortan la aplicación de esta libertad, controlando la misma.

${ }^{28}$ Vid. Colomer Viadel (El sistema político ..., o. c., págs. 104-120) con gran despliegue de citas del Diario de Sesiones. La libertad religiosa, junto a la polémica sobre la soberanía y las instituciones municipales (Ayuntamientos y Diputaciones) y la Milicia Nacional, considera el autor que son los "temas ideológicos y polémicos" del texto estudiado (págs. 85-143). 


\subsection{Organización institucional}

2.2.1. El Poder ejecutivo. La Corona ${ }^{29}$, como ya se observa en la base tercera de las preparadas por la Comisión ${ }^{30}$ va a resultar fortalecida en sus atribuciones, debido al mencionado pacto entre moderados y liberales, librándose de las limitaciones que estableciese el texto de Cá$\mathrm{diz}^{31}$, gozando junto a las Cámaras, de un veto temporalmente absoluto a los proyectos de ley durante esa legislatura (art. 39) ${ }^{32}$. Se configura como inviolable e irresponsable (art. 44) ${ }^{33}$, goza de iniciativa legislativa junto a cada Cámara (art. 36) ${ }^{34}$, convoca y suspende las Cortes y di-

${ }^{29}$ No podemos dejar de referirnos a la regulación de la Regencia, institución ésta que, si bien aparecía en el resto de Constituciones monárquicas, va a ser enormemente relevante en este periodo, debido a la minoría de edad de Isabel II y las enormes dificultades políticas de la época, con una clara utilización de la Reina niña por parte de las diferentes facciones políticas, situación ésta que terminó con el prestigio de la Institución. La minoría de edad regia se establecía en los catorce años (art. 56), bien que se adelantó inconstitucionalmente al 8 de noviembre de 1843, resultando nombrada Reina Isabel II a la edad de diez años. El artículo 57 permitía la Regencia única o la compartida por tres o cinco personas: durante todo el periodo, y hasta la inconstitucional mayoría de edad de Isabel II, la Regencia recayó en una sola persona: la Reina Regente hasta 1840 y luego en Espartero hasta 1843. También fue utilizado un artículo 58 en el que se preveía que, hasta que no se nombrase Regente por las Cortes, el Reino se gobernaría por el padre o madre del Rey o, en su caso, por el Consejo de Ministros, existiendo dos Ministerios-Regencia, el de Espartero y el de Joaquín María López. Vid. Tomas ViLlarRoya (o. c., pág. 59) y sus referencias a las actuaciones de la Reina Regente, de Espartero o de Olózaga.

${ }^{30}$ Vid. SeVILLA ANDRÉs, o. c., pág. 316. En concreto establecía la citada base que "Corresponde al Rey: Primero. La sanción de las leyes. Segundo: La facultad de convocar las Cortes todos los años, y de cerrar sus sesiones. Tercero: La de prorrogarlas y disolverlas; pero con la obligación en este último caso de convocar otras y reunirlas en plazo determinado». Los artículos 46 y 26 de la Constitución de 1837 hacen suya esta base.

${ }_{31}$ Así Sole Tura y AJa (o. c., pág. 35), calificando al nuevo régimen como Monarquía limitada. $Y$ es que, frente al artículo 172 del texto gaditano y sus numerosas limitaciones, el artículo 48 de la Constitución de 1837 reduce a seis las materias en las que el Rey debe estar habilitado por una ley especial. Vid. las competencias del Rey en Cavero Lataillade, I. y Zamora Rodríguez, T. Constitucionalismo histórico español. Madrid: Universitas, 1995, págs. 128-129.

${ }^{32}$ Como destaca ToRres del Moral (o. c., pág. 75), el término "legislatura» se entiende referido a la reunión anual de las Cortes, por lo que se asimila el régimen a lo estatuido en el artículo 17 de la Constitución francesa de 1830.

33 Vid. igualmente la literalidad del artículo 12 de la Carta francesa de 1830.

${ }^{34}$ Sigue así el modelo del texto francés indicado (arts. 14 y 15), alejándose del artículo 16 de la Carta de 1814 y del artículo 31 del Estatuto Real, textos éstos que abogaban por un régimen en el que la iniciativa legislativa pertenecía en exclusiva al Monarca.

(C) UNED. Revista de Derecho Político 
suelve el Congreso de los Diputados ${ }^{35}$, pero obligándose en este último caso a convocar otras Cortes y reunirlas en tres meses (art. 26) ${ }^{36}$; si el Rey incumpliese la convocatoria las Cortes se reunirían automáticamente el primero de diciembre de ese año (art. 27) ${ }^{37}$.

Bajo la Constitución de 1837 aparece, bien que de forma esporádica, la formalización del Gobierno como órgano colegiado; así se alude al mismo en el artículo 72 para exigir la presentación anual del presupuesto o aparece una mención al Consejo de Ministros al regular la Regencia provisional en el artículo $58^{38}$. Los ministros no aparecían exce-

35 Régimen similar al recogido en el artículo 42 de la Constitución francesa de 1830. Destacable institución la de la disolución de la Cámara baja, "elemento axial del sistema parlamentario", detalla TORRES DEL MORAL (o. c., pág. 75), indicando a continuación que, «bajo la Constitución de 1837, cuando los cuerpos colegisladores discrepaban en materia fundamental o el Gobierno perdía la confianza parlamentaria, el restablecimiento del equilibrio se podía buscar, en ambos supuestos, mediante la disolución de la Cámara, y en el segundo, también a través de la dimisión del Gobierno y el nombramiento de uno nuevo. (...). El lamentable ejercicio de esta facultad falseó el funcionamiento del sistema político a manos de grupos políticos y de la Corona. Aquéllos buscaban y ésta consentía, e incluso decidía, la formación extraparlamentaria del Gobierno para reestablecer el equilibrio institucional "a posteriori» y sin riesgos".

36 Vid. artículo 42 de la Carta de 1830, similar al artículo 50 del texto francés de 1814.

37 Tomas Villarroya (o. c., pág. 57-58) y Fernández Segado (Las Constituciones históricas... o. c., pág. 211) destacan la paradoja de que una Constitución que se aprueba fruto de un motín como el de La Granja, termine favoreciendo los poderes y autoridad del órgano frente al que se produjo. En palabras de TORRES DEL MORAL (o. c., pág. 74) «originada en un acto de violencia contra la Corona, no fue, sin embargo, una Constitución impuesta, sino que templó sus disposiciones de manera que le fueran aceptables a aquélla y a las fuerzas más conservadoras".

38 Se advierte de la consagración del régimen parlamentario que, en determinadas prácticas, ya se daba durante la época del Estatuto Real, siendo los ministros responsables ante las Cortes y pudiendo acudir a cualquiera de las Cámaras. Además el Gobierno necesita de la confianza de la Corona para evitar los posibles vetos a la legislación (SÁnchez Agesta o. c., pág. 273). Con Merino Merchán (o. c., pág. 90) podemos esquematizar las funciones del Gobierno en: a) propone al Rey las medidas necesarias para mantener el orden y seguridad; b) defiende los actos del Rey encaminados a adoptar dichas medidas; c) persuade a éste para que ejercitase la iniciativa legislativa; d) le propone nombramientos de funcionarios y cargos; e) elabora el Presupuesto y f) incita al Rey a que convocase, suspendiese las Cortes o disolviese el Congreso de los Diputados. Sobre la aparición de las primeras prácticas que suponen un precedente fáctico de la posterior aparición constitucional del régimen parlamentarista vid. VERA SANTOS ("La influencia del constitucionalismo francés...", o. c., págs. 166-167). 
sivamente regulados en la Constitución; son nombrados y cesados por el Rey (art. 47) y refrendan los actos del Monarca (art. 61) ${ }^{39}$, siendo su cargo compatible con el de diputado o senador (art. 62) ${ }^{40}$. Como posteriormente reseñamos, previa declaración del Congreso de los Diputados, son juzgados por el Senado ${ }^{41}$

2.2.2. El Poder legislativo. Las Cortes eran bicamerales ${ }^{42}$ y aparecen con una denominación que perdurará hasta la actualidad (el artículo 13 habla de Cortes, Congreso de los Diputados y Senado). Ambas Cámaras, cuyas sesiones eran públicas ${ }^{43}$, gozaban de atribuciones legislativas idénticas ${ }^{44}$; de atribuciones presupuestarias, en las que prevalece el Congreso en su tramitación, tal y como establece el artículo 37 en relación con el artículo 72; de competencias políticas, referidas en los ar-

39 Vid. arts. 12 y 13 de la Carta de 1830, continuando con idéntica regulación que la explicitada en los artículos 13 y 14 de la Carta de 1814.

${ }_{40}$ Nombramiento y cese regio, refrendo y, por ende, asunción de responsabilidad de los actos reales, así como compatibilidad con los cargos parlamentarios que se recogen igualmente en los artículos 12 y 46 de la Carta de 1830, al igual que ocurría, con las especificidades propias, en el régimen español del Estatuto Real y la influencia que éste recibe de la Carta francesa de 1814, tal y como ya hemos destacado dos notas más arriba.

41 Art. 40.4 de la Constitución española de 1837 y artículo 12 de la Ley de relaciones entre los Cuerpos Colegisladores, de 19 de julio de 1837. Esta ley se puede consultar en SEVILLA ANDRÉs o. c., págs. 337-338.

${ }^{42}$ Siguiendo el ejemplo de Francia en 1830 y Bélgica en 1831. Es significativo cómo aquel Argüelles monocameralista es ahora el Presidente de la Comisión de Constitución que considera básica la articulación del poder legislativo de manera bicameral. La base segunda que aparece en el Dictamen de la Comisión de Constitución, leído en la sesión del 30 de noviembre de 1836, ya indicaba que "las Cortes se compondrán de dos Cuerpos colegisladores, que se diferenciarán entre sí por las calidades personales de sus individuos, por la forma de sus nombramiento, y por la duración de su encargo; pero ninguno de estos cuerpos será hereditario ni privilegiado (...).» (Vid. SEVILLA ANDRÉs, o. c., pág. 315).

43 Vid. artículo 35 de la Constitución de 1837, que es adoptado por el artículo 34 del texto español de 1845, bien que cabe excepcionalmente, si las deliberaciones exigían reserva, el secreto de las mismas. El artículo 27 de la Carta francesa de 1830 también aboga por la publicidad de las sesiones, siguiendo también este régimen el Estatuto Real (art. 48).

${ }^{44}$ La Base segunda antes citada continuaba indicando que los Cuerpos colegisladores "serán iguales en facultades; pero las leyes sobre contribuciones y crédito público se presentarán primero al cuerpo de Diputados, y si en el otro sufrieran alguna alteración, que éstos después no admitiesen, pasará a la sanción real lo que los Diputados aprobaren definitivamente». El artículo 13 del texto de 1837, alude a las dos Cámaras como "iguales en funciones». Respecto a las discusiones habidas al respecto vid. Fernández SEgADO ("Las bases...», o. c., págs. 720-721) 
tículos 40 y 45 (reciben el juramento regio, resuelven las dudas en el orden sucesorio, o nombran tutor o Regente cuando procediese), y, por último, de atribuciones de control (art. 40) bien que el mismo se seguía refiriendo técnicamente al penal ${ }^{45}$, aunque ya sabemos que, por el propio devenir del régimen, el sistema parlamentario acabase imponiéndose, y con él, la consiguiente responsabilidad política de los ministros ante las Cámaras, como ya ocurría en tiempos del Estatuto Real ${ }^{46}$.

Encontramos, por tanto, que el bicameralismo -otra de las pautas que definirán el ideario moderantista- se acepta unánimemente, ya que la discusión en las Cortes constituyentes no versó sobre el establecimiento o no del bicameralismo, sino que se discutió profusamente los aspectos organizativos, de nombramiento, etc. , de un Senado que, como reseña Olózaga, "es el punto capital de la Constitución, y el asunto más difícil de arreglar en todas las leyes fundamentales ${ }^{47}$, justificando la dualidad de Cámaras con nuevos argumentos (mejora la consecución del entendimiento de la opinión nacional, pudiendo así ser gobernados por ésta ${ }^{48}$ ), acudiendo a otros ya conocidos, configurándose un Senado que actúe como cuerpo intermedio entre la Monarquía y el pueblo, entre la permanencia y la evolución, simbolizando por tanto la unión entre el pueblo y la Corona. Su carácter de cuerpo conservador y su aportación a la calidad de las leyes, junto a los ejemplos foráneos, son también alegados en una tramitación que fue pacífica respecto a este tema, echándose de menos la motivación histórica alegada en el Estatuto Real ${ }^{49}$.

45 Idéntica situación encontramos en Francia en el artículo 47 del texto de 1830, siguiendo el modelo de la Carta de 1814 (arts. 33, 55 y 56) y del Estatuto Real (art. 139 del Reglamento de los Estamentos).

46 Recogemos nuevamente la opinión de FERnÁndez Segado (Las Constituciones históricas... o. c., pág. 208).

47 Diario de Sesiones de las Cortes constituyentes de 1836-1837, pág. 2678.

48 Así se observa en el "Dictamen de la Comisión ..." citado. R. BERTELSEN REPETто (El Senado en España. Madrid: IEA, 1974, pág. 272), considera que el meritado constituye el argumento con mayor peso en este momento histórico, desarrollando posteriormente los demás que ya hemos aludido. Vid. FernándeZ SEgAdo ( «Las bases...", o. c., págs. 713-717) en cuanto a la discusión sobre la solución bicameral.

49 Vid. Vera SANTOS "La influencia del constitucionalismo francés ...", o. c., págs. 171-172, respecto a los argumentos recogidos en el Estatuto Real a favor del bicameralismo. Recoge los argumentos a favor del bicameralismo aludidos en la tramitación parlamentaria de la Constitución de 1837, COLOMER VIADEL (El sistema político ..., o. c., págs. 207-220), aludiendo a la mejora en la representatividad, el equilibrio institucional, la mejora de la técnica legislativa o los modelos de derecho comparado. 
Al Congreso de los Diputados se consagra el Título IV de la Constitución, donde encontramos cómo, en circunscripciones provinciales, se nombrará un diputado por cada cincuenta mil almas (art. 21), por sufragio directo (art. 22) ${ }^{50}$, con un mandato de tres años (art. 25) ${ }^{51}$, requiriéndose, para resultar elegido, ser español, seglar y mayor de veinticinco años, junto a cualquier otra condición que reseñase la ley electoral (art. 23). Esta norma sería publicada el 20 de julio de 1837, al mes de promulgada la Constitución, y en la misma se observaba un sufragio directo censitario "amplio en el número y en la variedad de electores ${ }^{52}$.

En lo que respecta al Senado, es regulado en el Título III del texto constitucional (arts. 14 a 20). El artículo 15 nos muestra una forma de elección bastante novedosa, influida sin duda por el artículo 19 del proyecto constitucional de la sociedad isabelina ${ }^{53}$. Así los senadores lo son

50 «Los Diputados a Cortes se elegirán por el método directo, y podrán ser reelegidos indefinidamente", reza la base cuarta del Dictamen de la Comisión de Constitución varias veces citado. Se abandona definitivamente el sufragio indirecto del texto de 1812 y se constitucionaliza una elección directa que ya se introdujo, como vimos, en la época del Estatuto Real (VERA SANTOS "La influencia del constitucionalismo francés ...", o. c., págs. 173-174), régimen similar al que encontramos, siguiendo la Carta de 1814 (arts. 35-40), en el texto de 1830 (bien que el artículo 30 difiere la organización de los colegios a las normas ordinarias, como también hacía el artículo 35 del texto de 1814). Nuevamente nos remitimos a FERNÁNDEZ SEGADO ("Las bases...", o. c., págs. 721-728) para observar los argumentos que se esgrimen a favor y en contra del modelo electoral que se termina adoptando.

${ }^{51}$ Cinco son los años de mandato de los miembros de la Cámara Baja en la Carta de 1830 (art. 31), siguiendo lo prescrito en el artículo 37 del texto de 1814.

52 Cita y datos de Tomás VilLarRoya (o. c., pág. 55). Con la finalización de la guerra civil, la perfección de los mecanismos electorales, amén de la corrupción del sufragio, el cuerpo electoral pasó de doscientos cincuenta y siete mil electores en 1837 a más de cuatrocientos veinte mil en 1840 y a un millón al final del régimen. Contribuyentes, propietarios, capacidades, labradores o colonos siempre que cumpliesen determinadas garantías económicas, se incorporaban al sistema mediante el derecho de sufragio activo. Entretenidas las referencias de SÁNCHEZ AGESTA (o. c., págs. 184191) a la corrupción electoral —bien que en un periodo histórico más amplio-, con citas de Estébanez Calderón y Borrego. Vid. al respecto de las diferentes elecciones habidas bajo la ley electoral de 1837 (desde la de 22 de septiembre de dicho año a la del 3 de septiembre de 1844) CASES MÉNDEZ, J. I. "La práctica electoral bajo la Constitución de 1837", en Revista de Derecho Político, n. ${ }^{\circ}$ 20, 1983-1984, págs. 67-93. Incluye el autor numerosas referencias jurídicas, políticas y de opinión de los protagonistas de cada momento.

53 Vid. Vera SANTOS "La influencia del constitucionalismo francés ...", o. c., pág. 172. El texto de la sociedad isabelina (art. 19) mencionaba a las Diputaciones provinciales como órganos encargados de elevar las ternas al Rey. En la discusión de 
mediante elección doble y consecutiva ${ }^{54}$ : elegidos por el Rey a propuesta, en lista triple, de los electores que en cada provincia nombran los diputados a Cortes. Cada provincia propone al menos un senador, aunque el número en concreto se basa en razones poblacionales (art. 16). Los requisitos para acceder al cargo son ser español, mayor

este tema se pusieron de manifiesto diversas tendencias que iban desde la elección popular hasta dotar al Rey de total libertad. Destacan las propuestas de Gorosarri (el Rey elegía a la mitad de los senadores haciendo lo propio los electores con los restantes) y de Venegas (la Corona podría nombrar nuevos senadores siempre que los elija de listas populares). Se pueden encontrar en las págs. 2660 y ss. del Diario de las Cortes constituyentes de 1836-1837. Tomás VILLARROYA (o. c. , pág. 54), cita la opinión negativa de Donoso Cortés refiriéndose a estos senadores por elección doble y consecutiva: "el pueblo no verá en ellos a sus hombres; el Rey no reconocerá en ellos su obra; estos nuevos aristócratas no tendrán genealogía». Citas también contrarias al sistema de reclutamiento en Fernández Segado (Las Constituciones históricas... o. c., pág. 174) reflejando a Bertelsen. En este apartado del reclutamiento de los senadores, la Constitución de 1837 se separa del modelo estatuido en la Francia de 1814 (art. 27) y 1830 (art. 23), textos en los que el Rey nombra a los senadores en número indefinido, de por vida o con carácter hereditario. Como destaca Colomer Viadel (El sistema político ..., o. c., págs 347 y ss y 659-660), también influyen en la regulación del Senado de la Constitución española de 1837, los artículos 40 y 43 de la Constitución brasileña de 1823, en la que el Emperador elige ternas de senadores resultantes de las listas triples que se presentan en circunscripciones provinciales. En las páginas 346 y 347 alude también el autor a la influencia en el texto del proyecto de Constitución isabelina.

${ }^{54}$ Vid. Vera Santos, J. M. Senado territorial y presencia de notables. Madrid: Senado, 1998. En las páginas 108-112, establecemos una clasificación jurídica (que no histórica o política como las existentes hasta la fecha en la doctrina), de la distinta tipología de pares, atendiendo a tres factores: a) el modo de adquisición de la condición senatorial (senadores natos, bien por cargo público, bien por su vinculación familiar con el Monarca; y electivos por sufragio directo o indirecto; por designación regia o por elección doble y consecutiva); b) por la duración del mandato los senadores se catalogan como vitalicios (o no limitados temporalmente) y los que sí encuentran un límite, ya sea temporalmente determinado (senadores limitados stricto sensu) o sometidos a la condición resolutoria del mantenimiento del cargo matriz que les vinculaba al escaño senatorial; c) en tercer lugar, teniendo en cuenta la transmisión o no del cargo, los senadores se definían como hereditarios o no hereditarios. Calificamos como de elección doble y consecutiva aquel procedimiento electivo en el cual se necesita de la confluencia de dos voluntades absolutamente autónomas que se ejercen de manera consecutiva, en este caso electores provinciales-Rey. Así distinguimos estos senadores (en cuya elección participa en última instancia el Monarca, pero cuya decisión aparece acotada por la previa participación de otro órgano), de aquéllos que lo son por libre designación regia. En las páginas 50-60 subsumimos en esta calificación tanto el modelo del proyecto de la sociedad isabelina como el de esta Constitución de 1837. 
de cuarenta años y los demás que se reflejen en una ley electoral (art. $17)^{55}$. El Senado se renovaría por terceras partes en orden a la antigüedad cada vez que se renueve el Congreso, pudiendo los senadores ser reelegidos (art. 19) ${ }^{56}$. Junto a los senadores elegidos según el procedimiento antes visto, el artículo 20 deja la puerta abierta a la presencia de los hijos del Rey y del heredero inmediato de la Corona, como senadores por derecho propio ${ }^{57}$. El número de senadores será igual a las tres quintas partes de los miembros de la otra Cámara (art. 14), pudiendo ser propuestos por cualquier provincia (art. 18) en nú-

55 Esta es la ley datada el 20 de julio de 1837. Si el artículo 22 del proyecto de la sociedad isabelina ya establecía unas categorizaciones que, por su amplitud y generalización, no resultaban especialmente limitativas, en 1837 no aparecen categorías de acceso referidas a los senadores nombrados y elegidos por el Monarca dentro de esas ternas provinciales. No obstante, los requisitos de edad y económicos (estos últimos reflejados en el artículo 56 de la Ley electoral: renta propia o sueldo de más de treinta mil reales vellón al año o el pago de tres mil de contribución por subsidio de comercio, pudiendo acumularse tales conceptos según un baremo que el propio precepto establece), tienden a conseguir que la burguesía liberal pudiese formar parte de esta Cámara, en virtud, con total seguridad, de una incipiente idea de igualdad de los ciudadanos (aunque ésta no se reflejase en la universalización total del sufragio), que ya se observa en el propio Dictamen de la Comisión que propone las bases para la reforma constitucional, donde se puede leer: «El brazo del despotismo los ha igualado a todos (...), todos eran vasallos; ahora todos somos ciudadanos" (SEVILLA ANDRÉs, o. c., págs. 312-313). A pesar de ello posteriormente se opta por la existencia de distinciones en la duración, nombramiento, etc., entre los miembros de ambas Cámaras.

56 Como ya hemos indicado, el Senado se renueva por terceras partes en orden a la antigüedad, cada vez que se produzcan elecciones al Congreso de los Diputados (art. 19). Por tanto el mandato senatorial goza de una duración de nueve años, pudiéndose optar a reelección. Nos encontramos ante un Senado que, salvada sea la excepción que prevé el artículo 20 referida a la presencia en el Senado de los hijos del Rey y del sucesor al Trono, no admite el mandato vitalicio, apartándose así de los proyectos de la sociedad isabelina (art. 20) y del Ministerio Istúriz (art. 17).

57 Según también indicaba el artículo 23 del proyecto de la sociedad isabelina. Esta figura influirá decisivamente en el modelo que luego se establecerá en las formulaciones constitucionales de 1845 (art. 18), Proyecto de Bravo Murillo (art. 12), "non nata" de 1856 (art. 23) y en el artículo 21 de la Constitución de 1876. Se discutió sobre si, al admitir la senaduría basada en la relación de parentesco con el Rey, no se estaba violentando la antes citada Base segunda de las establecidas por la Comisión. Al final se consideró que sería beneficioso para la educación de los miembros de la Familia Real, además de encontrar apoyos en el ejemplo inglés. Respecto a este tipo senatorial, ha de recordarse que el artículo 26 de la Carta francesa de 1830 también permite la presencia como Pares de los príncipes de sangre, asimilando el artículo 30 de la Carta de 1814, que también permitía el acceso como pares a los miembros de la familia real. 
mero proporcional al de su población, con un mínimo de uno por provincia (art. 16) ${ }^{58}$.

En cuanto al Poder Judicial (Título X, arts. 63 a 68), es la primera vez que aparece con tal denominación, asentándose en los principios de exclusividad (art. 63), publicidad en la jurisdicción criminal (art. 65), inamovilidad de jueces y magistrados (art. 66) y de responsabilidad de los mismos (art. 67) ${ }^{59}$.

Con todo, la falta de estabilidad institucional, la imposibilidad de las sucesivas Regencias y de la joven Reina para mantener la autoridad de la Corona, junto a la utilización de la misma con fines partidistas, los pronunciamientos militares, la inestabilidad de los Gobiernos y su falta de apoyo, el abuso gubernamental de la facultad de disolución de unas Cortes (dos veces en 1839) que en ningún caso apuraron sus tres años de mandato, la corrupción electoral, amén de otra serie de consideraciones, hicieron de la aplicación de un texto que ofrecía posibilidades de concordia, una hipótesis que nunca se alcanzó ${ }^{60}$.

\section{LA CONSTITUCIÓN DE LA MONARQUÍA ESPAÑOLA DE 23 DE MAYO DE 1845}

\subsection{Introducción. Parte dogmática}

La Reina Gobernadora abdicó el 12 de octubre de 1840, debido al conflicto latente por la denominada Ley Municipal ${ }^{61}$, iniciándose pos-

${ }^{58}$ El artículo primero de la ley electoral de 20 de julio de 1837 prescribe que "todas las provincias de la Península e islas adyacentes nombrarán un diputado por cada cincuenta mil almas de su población y propondrán por cada ochenta y cinco mil tres candidatos para el Senado". Si resultase un exceso de la mitad del número exigido, se nombra a un diputado y se proponen también tres senadores (art. 2). En virtud de lo anterior, el número de senadores quedaba establecido en ciento cincuenta y cuatro miembros. Se observa así una tendencia de mayor concretización cuantitativa respecto al número de senadores, acabando con el carácter indefinido prevalente en los regímenes del Estatuto Real (art. 9) y del Ministerio Istúriz (art. 17).

59 Seguimos a Merino Merchán (o. C., pág. 90) y a Fernández Segado (Las Constituciones históricas ..., o. c., págs. 212-213).

60 Vid, para mayor abundamiento TOMÁs ViLLARROYA (o. c., págs. 61-64) con citas de Pacheco, Borrego o Joaquín María López. También Fernández Segado (Las Constituciones históricas ... o. c., págs. 214-215) o MERINO MERCHÁN (o. C., págs. 90-91).

61 Por todos, TorRes Del Moral (o. c., págs. 80-82), realzando la importancia de la regulación que pretendía dicha ley, ya que «en la batalla de los Ayuntamientos se jugaban las elecciones generales". Y es que la ley del 40 hacía electivo el cargo de Al- 
teriormente la Regencia del general Espartero hasta julio de 1843, fecha en la que éste se ve obligado a exiliarse a Inglaterra. Ante las reticencias que suscitaba nombrar de nuevo como Regente a María Cristina, el nuevo gobierno de Joaquín María López decide proclamar la mayoría de edad de Isabel II, haciendo caso omiso de lo previsto en el artículo 56 de la Constitución de $1837^{62}$.

Después de los ministerios relámpagos de Olózaga y González Bravo, en mayo de 1844 el general Narváez pasó a ocupar los cargos de Presidente del Consejo y de Ministro de la Guerra y afronta la reforma de la Constitución de $1837^{63}$, optando con ello por un camino interme-

calde y las Diputaciones Provinciales eran igualmente elegidas por un cuerpo electoral idéntico al que votaba para el Congreso de los Diputados.

62 Vid. nota 29. La comunicación del Gobierno sobre la declaración de la edad de S. M. la Reina Doña Isabel II y el dictamen de la Comisión correspondiente puede haIlarse en SEVILLA ANDRÉs, o. c. vol. I. págs. 347-350.

${ }^{63}$ Sobre la naturaleza jurídica de las Cortes de 1844 y su obra final, existen diversas opiniones contradictorias. Realmente, al seguir en vigor la Constitución de 1837 y ser ésta flexible, no era condición necesaria el dotar de carácter constituyente a las Cortes que procedieron a la reforma que da lugar al texto de 1845. Vid. Tomás VILLARROYA (o. c., pág. 66), con citas en las que, incluso los detractores de la reforma, admiten el proceso formal que se sigue.

Existe igualmente polémica sobre un texto del que también se discute si es una mera reforma o inaugura un nuevo régimen. Al respecto de lo anterior, SÁNCHEZ Agesta (o. c., págs. 287-292) y TORRES DeL MORAL (o. c. pág. 84), son partidarios de la primera de las opciones antes dichas, enmarcando ambos textos dentro del liberalismo doctrinario, aunque en 1845 se produce una inclinación hacia el pensamiento conservador. También Tomas Villarroya (o. c., pág. 68). Fernández Segado (Las Constituciones históricas ..., o. c., págs. 226-227), en su posterior argumentación, reseñando las diferencias entre los textos de 1837 y 1845, parece indicar que parte también de esta premisa, explicitando únicamente las modificaciones realizadas. En contra se muestran Sole Tura (o. c. pág. 40), Fraile Clivilles (Introducción al Derecho Constitucional Español. Madrid: 1975, pág. 260), o Clavero (Manual de historia constitucional de España. Madrid: Alianza, 1989, pág. 72 y ss). Nosotros seguimos a los primeros autores citados, y a DE ESTEBAN, GARCíA FERNÁNDEZ y EsPíN (o. c., págs. 52-53), en cuyos esquemas se observa el evidente paralelismo conceptual con el texto de 1837, salvados sean las especificidades que se explicitarán. Interesante el artículo de M. A. Tomás FONT DE MORA "Las Cortes revisoras de 1844/45. Su fisonomía", en Revista de las Cortes Generales, n. ${ }^{\circ} 22$, 1991, págs. 55-77, sobre todo para observar las posturas de las dos líneas minoritarias que abogaban por no reformar la Constitución de 1837: los puritanos de Pacheco (denominados "disidentes» por la autora), quiénes se oponían a reformar la Constitución de 1837 «por juzgarla innecesaria y contraproducente» (págs. 57-59), y los moderados autoritarios o monárquicos puros con Tejada a la cabeza, considerando éstos que debía volverse a un régimen monárquico tradicional (págs. 60-62). Muy interesante también el apartado al que la autora denomina "el episodio Tejada» (págs. 66-70) en el que se 
dio entre las distintas posturas de sus propios correligionarios que preconizaban el mantenimiento del texto de 1837 (puritanos de Pacheco) o incluso la vuelta al Estatuto Real (los seguidores del marqués de Viluma).

En cualquier caso esta Constitución, que sufrirá a su vez sucesivos intentos de reforma ${ }^{64}$, presenta como aspectos más destacables respecto a su predecesora - a cuyo estudio nos remitimos en las cuestiones no reseñadas como novedosas-, la derogación jurídico-política del teórico principio de soberanía nacional que aparecía en la Constitución de 1837, siendo sustituido por la soberanía compartida entre el Rey y las Cortes ${ }^{65}$, tesis doctrinaria moderantista que encuentra su apoyo en

refieren las críticas vertidas cuando el diputado monárquico "leyó» su discurso, siendo atacado por ello al calificar el mismo de "folleto", considerando que las intervenciones eran personales y formaban parte de un todo (la discusión, la argumentación y contra argumentación), que no permitía el discurso previo y escrito, ya que no se había escuchado la opinión del contrario. ¡Qué tiempos!

${ }^{64}$ Así se consideran los proyectos de los gabinetes de Bravo Murillo y Roncali, la Constitución "non nata" de 1856, el Acta Adicional de O'Donnell, la reforma de 1857 y la Ley de Mon. $Y$ es que se puede aplicar al texto moderantista aquel dicho de que "quién a hierro mata, a hierro muere". Abunda, como antes hemos reseñado, Varela Suances-Carpegna ("La Constitución..." o. c., págs. 103-104) en lo inadecuado de aprobar el texto de 1845, acabando con el carácter transaccional del texto constitucional precedente y con las posibilidades que el mismo incluía, tal y como incluso los moderados puritanos, con Istúriz a la cabeza, indicaron, aludiendo a que "lo que nosotros podemos hacer no debemos hacerlo porque lo pueden todos", temiendo la política de cambios constitucionales cada vez que se produjese un cambio de partido en el gobierno. Similar argumentación encontramos en MEDINA MuÑóz, M. A. "La reforma constitucional de 1845", en Revista de Estudios Políticos, n. ${ }^{\circ}$ 203,1975 , págs. 75-104 (80-81), destacando cómo el texto de 1845 abre el camino a las sucesivas reformas que sufre el propio texto citado $y$, sobre todo, el régimen constitucional español. "Era una Constitución de partido contra otro partido», destaca TORRES del Moral (o. c., pág 86). Siguiendo nuevamente a TOMÁs VILLAROYA (o. c., págs. 66-67), uno de los autores que más y mejor ha estudiado el periodo isabelino y el texto de 1837, "la necesidad y oportunidad de la reforma" acaecida en 1845 no era tal, ya que el texto de 1837 permitía diferentes opciones de gobierno, siendo innecesaria la modificación constitucional que, como veremos, afecta fundamentalmente a la composición del Senado. Encontrándonos con un texto flexible, posiblemente no hubieran los moderados de proceder al establecimiento de un "turno de cambios constitucionales partidistas". Dice para finalizar TOMAS VILLARROYA que "el número venció a la razón" y la trayectoria posterior de nuestro constitucionalismo así lo atestiguará.

65 Eso sí, hablamos en ambos casos de la redacción del Preámbulo constitucional, no de que ninguno de los citados principios (soberanía nacional-soberanía compartida) apareciese en el articulado de ninguno de los textos constitucionales re- 
la teoría de la Constitución interna que, en la Restauración, tan buen servicio le prestó a Cánovas del Castillo66.

En materia de derechos y libertades se suprime el jurado como órgano calificador de los delitos de imprenta (art. 2), con restricciones legales posteriores ${ }^{67}$ además de desaparecer la unidad de fuero, declarando igualmente el nuevo artículo 11 la confesionalidad de la Nación española, adelantándose así a la firma del Concordato de 1851 y alejándose de la regulación del texto de 1837, que abogaba por la tolerancia religiosa ${ }^{68}$.

ferenciados. Así Medina MuÑoz ("La reforma constitucional ...», o. c., pág. 95), alude en su punto $\mathrm{V}$ a la cuestión de la "Constitución histórica y soberanía", destacando la evolución de este principio en los textos y proyectos anteriores, y considera que el mayor cambio habido en este nuevo texto respecto al de 1837 se realiza en el Preámbulo, en alusión a la nueva doctrina de la soberanía compartida. Vid. TomÁs Font DE Mora, M. A. «El Preámbulo de la Constitución de 1845», en Revista de Derecho Político, n. ${ }^{\circ} 39,1995$, págs. 81-106, en especial págs. 84-92, en las que, primero, coteja los Preámbulos de 1837 y 1845; posteriormente alude a la supresión del principio de soberanía nacional en base a una trilogía argumental que califica de "dispar» (el carácter abstracto del principio citado, su dudosa utilidad y su posible utilización como pretexto para la rebelión); y, por último estudia el nuevo principio de soberanía conjunta Rey-Cortes y su uso en la fórmula de promulgación de la propia Constitución de 1845. Como ya indicamos anteriormente (vid. nota 19) consideramos que en el texto de 1837 ya se aboga "de facto" por un régimen de soberanía compartida. Como indica TORRES DEL MORAL (o. c., págs. 84-85), el principio de mayor trascendencia, el de soberanía, "discrepa en la superficie y coincide en el fondo" (se refiere el autor al cotejo de los textos isabelinos de 1837 y 1845).

66 Vid., por su mención explícita y resumida a la Constitución de 1845, y a la doctrina de la Constitución histórica (interna, diría Cánovas) TORRES DeL MoRAL (o. c., págs. 67-71) VARELA SUANZES-CARPEGNA, J. "La doctrina de la Constitución histórica: de Jovellanos a las Cortes de 1845 ", en Revista de Derecho Político, n. ${ }^{\circ} 39,1995$, págs. 45-79 (especialmente las páginas 75-79). Vid. también, respecto a esta cuestión ToMÁs FONT DE MORA "El Preámbulo de ...", o. C., págs. 95-98. De mayor amplitud CÁNOVAS SÁNCHEZ, F. El moderantismo y la Constitución de 1845. Madrid: Fundación Santa María, 1985, y ComelLAS, J. L. Los moderados en el poder 1844-1854. Madrid: CISC, 1970.

67 SÁNCHEZ Agesta indica que el cambio se desarrolla para lograr conciliar «la libertad y el orden" (o. c., pág. 292-294), ante el uso que se daba a la libertad de imprenta, regulada a mayor control ya en abril de 1844, librando del jurado los delitos de injurias y calumnias. Vid. Pérez-Prendes Muñoz ArRaco, J. M. "De «metafísica constitucional». Ensayo de comentario al dictamen "de reforma" en 1845», en $R e$ vista de Derecho Político, n. ${ }^{\circ} 39,1995$, págs. 9-43 [26-28].

68 El artículo 6 de la Carta francesa de 1814 establece la confesionalidad del Estado, bien que la Carta de 1830 la transforma en tolerancia. 


\subsection{Organización institucional}

3.2.1. El Poder ejecutivo. El poder de la Corona se ve fortalecido por la desaparición de la autoconvocatoria de las $\operatorname{Cortes}^{69}$ o del permiso para contraer matrimonio regio, antes recogidos en los artículos 27 y 48 de la Constitución de 1837. El poder ejecutivo no es modificado constitucionalmente, aunque la función de gobierno se ve empañecida por una inestabilidad que aparece como fruto de enfrentamientos políticos, no sólo entre moderados y progresistas, sino también por la división existente en cada bando, provocando un clima alterado que se refleja en los intentos de modificación del texto constitucional ${ }^{70}$.

3.2.2. El Poder legislativo. Las Cortes Generales desarrollan una serie de actos político-institucionales que se encuentran disminuidos respecto a lo establecido en el texto de 1837, ya que en 1845 desaparece, por un lado, la prescripción del artículo 48 de aquel texto referido a la necesidad del Monarca de autorización legal para ausentarse del Reino y para contraer matrimonio ${ }^{71}$, señalando el nuevo artículo 47 que basta con que el Monarca comunique a las Cortes que va a contraer matrimonio, debiendo éstas, eso sí, aprobar las estipulaciones matrimoniales. Por otro, el artículo 57 del nuevo texto establece una Regencia "de iure" con base hereditaria y sucesoria, frente a la electiva por las Cámaras de su homóloga de 1837. Por su parte, el artículo 39 recoge idénticas competencias de las Cortes a las establecidas en el artículo 40 de 1837, salvo lo referente a la resolución de dudas de hecho o de derecho en orden a la sucesión.

69 Tampoco cabe la autoconvocatoria en los textos franceses de 1814 (art. 50) y 1830 (art. 42). Vid. CAVERO y ZAMORA, O. c., págs. 150-151, en lo tocante a las competencias regias.

70 Vid. Merino Merchán (o. C., págs. 102-104) en la que se relatan con claridad las diferentes facciones moderadas y progresistas, la inestabilidad ministerial (el Gabinete Cleonard, con menos de un día de duración) y el actuar de los políticos de la época: Narváez, la vuelta de Espartero, la aparición de O’Donnell y la "vicalvarada», Canovas y sus primeros lances políticos, el burócrata Bravo Murillo, etc. . Esta inestabilidad no es sólo gubernativa sino que también se observa en el Parlamento. Es una de las conclusiones que se obtienen del trabajo de R. LAPUENTE ARAGó "La suspensión parlamentaria durante el reinado de Isabel II", en Revista de Derecho Político, n. ${ }^{\circ} 39,1995$, págs. 159-211, páginas en las que se destaca la indefectible unión entre la suspensión regia y la postrer disolución de las Cortes. Con un simple acercamiento a los cuadros de las páginas 188, 209, 210 y 211, nos damos cuenta de la citada inestabilidad cameral.

71 Respecto a la problemática política del futuro matrimonio de Isabel II y la modificación del articulado del texto liberal al moderantista, vid. Pérez-PrEndes MuÑOZ ARRACO «De «metafísica...», o. c., págs. 40-42. 
Las Cámaras siguen gozando de iniciativa legislativa junto al Rey (artículo 35 que sigue en este punto al artículo 36 de la Constitución de $1837)^{72}$, pudiendo también interponer un veto legislativo (art. 38) ${ }^{73}$. Por otra parte, el artículo 65 recogía la compatibilidad entre el mandato parlamentario y el cargo de ministro. En el aspecto presupuestario, al contrario de lo establecido en el artículo 37 de la Constitución de 1837, el 36 de la de 1845 sólo reconoce la preferencia del Congreso en la presentación de tales leyes, desapareciendo por tanto la prevalencia de la Cámara baja a la hora de decidir la votación de las mismas, en caso de desacuerdo con el Senado ${ }^{74}$.

Mientras el articulado referido al Congreso de los Diputados establece, frente a la regulación anterior, la elección de sus miembros en distritos uninominales y la prolongación del mandato parlamentario de tres a cinco años (art. 24) $)^{75}$, el Senado va a sufrir una reforma sustancial en favor del sentir moderado que encarnaban tanto las Cortes de 1844 como un Gobierno que consiguió su propósito de organizar el Senado

72 Esta iniciativa legislativa compartida entre el Rey y las Cortes viene influenciada por el artículo 15 del texto francés de 1830, que se separa de la iniciativa legislativa exclusiva que el artículo 16 de la Carta de 1814 establecía y que acoge el Estatuto Real en su artículo 31.

73 Idéntico tenor presentaba el artículo 39 de la Constitución de 1837.

${ }^{74}$ La Carta francesa de 1814 indica que la proposición de ley de impuestos debe ser enviada en primer lugar a una Cámara de Diputados que debe admitirla antes de pasar a ser discutida en la Cámara de Pares (arts. 17 y 47). El artículo 15 de la Carta de 1830 establece también la preferencia temporal de voto en la Cámara de Diputados.

75 El mandato de cinco años que establece el artículo 24 del nuevo texto, obviando los tres años que establecía el artículo 25 de la Constitución de 1837, resulta también influenciado por el artículo 31 del texto galo de 1830 y se debía al intento de estabilizar la vida parlamentaria. Intento inútil, ya que bajo la hégira del texto moderantista las disoluciones anticipadas y la convocatoria de elecciones se continúan sucediendo (diez elecciones en veinticuatro años) y sólo dos Congresos agotaron el quinquenio de mandato. Indicar con FERnández Segado (Las Constituciones históricas ... o. c., pág. 229) como la Ley electoral de 18 de marzo de 1846 instauró la elección por distritos uninominales (arts. 1 y 2), elevando las condiciones de electores y elegibles, pudiendo ser electores quiénes pagasen cuatrocientos reales de impuesto directo o determinadas capacidades que pagasen doscientos (arts. 14 y 16), pasando así el cuerpo electoral a estar compuesto por unos cien mil individuos (menos del 1 por ciento de la población). Son elegibles como diputados los españoles, seglares, mayores de veinticinco años y con una renta de doce mil reales de vellón en bienes raíces o el pago de mil en contribución directa (arts. 4,5 y 6). Vid. fragmento de la norma en SEVILLA ANDRÉs (o. c., págs. 383-383) y datos referidos a las diferentes normativas y elecciones realizadas, fechas de aperturas de Cámaras, periodificados según proyectos de reforma y texto "non nato" en ULL PONT, E. «El sistema electoral de la Constitución de 1845», en Revista de Derecho Político, n. ${ }^{\circ}$ 39, 1995, págs. 107-157. 
estableciendo un mandato vitalicio para unos miembros elegidos directamente por el Monarca entre capacidades y en número ilimitado ${ }^{76}$.

El Título $1 \mathrm{II}^{77}$ de la Constitución de 1845 configura un Senado muy determinado por la actuación real ${ }^{78}$ ya que el número de senadores es

76 Vid. «Proyecto del Gobierno sobre la reforma de la Constitución» y "Dictamen de la Comisión sobre la reforma de la Constitución", en SEviLLA ANDRÉs o. c., vol I, págs. 351-370. No se polemizó sobre la oportunidad de la Segunda Cámara ya que la discusión recae sobre sus aspectos organizativos, predicándose de ésta una serie de bondades que ya nos son conocidas. Así, por ejemplo, se alude al argumento histórico, aunque sin finalidad de restablecer el sistema estamental, a la necesidad de establecer un cuerpo intermedio y moderador que represente distintos intereses y que perfeccione la actividad legislativa. También hace acto de presencia su carácter conservador tanto de la tradición como del Estado social, desapareciendo el argumento utilizado en 1837 referido a la consecución de un mayor conocimiento de la opinión nacional (SevilLa Andrés, D. «El Senado en 1845». Homenaje a D. Nicolás Pérez Serrano. Madrid: Edit. Reus. 1959. vol. II. págs. 3-28). Incide en este aspecto MEDINA Muñoz, M. A. "Las Cortes en la Constitución de 1845». Revista de Estudios Políticos. 1976, n. ${ }^{\circ}$ 208-209. págs. 131-146. Expresa SÁNCHEZ AgESTA (o. c., pág. 290) que "Esta nueva configuración del Senado es una de las piezas más importantes y sugestivas de la nueva Constitución (...). se rechaza la Cámara nobiliaria, según el patrón inglés de la Cámara de los Lores; se rechaza también la Cámara electiva, de que (sic) ofrecía un modelo la Constitución belga (modelo que fue acogido por la Constitución de 1837), para imitar el modelo francés de Senado (...). Es la doctrina de las aristocracias naturales (...). Esta opción por este modelo de composición del Senado, no debemos olvidar, se realiza con la clara finalidad de lograr "un Senado llamado a ser freno de los excesos del Congreso de los Diputados", como expresamente indica la profesora González Hernández en una excelente obra en la que hilvana un "constitucionalismo común" a partir de la realidad histórico-constitucional europea (GoNZÁLEZ HERNÁNDEZ, E. Breve historia del constitucionalismo común (1787-1931). Madrid: Servicio de Publicaciones de la Universidad Rey Juan Carlos, 2006, pág. 145).

77 Este Título III fue objeto en su conjunto de cuatro enmiendas a la totalidad, tres de ellas en el Congreso de los Diputados (enmiendas de Montevirgen, Perpiñá y Pacheco) y una en el Senado (duque de Gor). Montevirgen, en la única enmienda que se tomó en consideración, diferencia entre senadores hereditarios, de dignidad $y$, en tercer lugar, vitalicios de nombramiento real entre categorías. Los hijos del Rey y del heredero inmediato a sucederle también son natos por razones de sangre a la edad de veinticinco años. Perpiñá distingue entre los nobles y dignidades en razón de su cargo, que lo son por derecho propio junto a los hijos del Monarca y del Príncipe de Asturias, frente a los de nombramiento real entre categorías. Pacheco prefería un Senado donde cupiesen senadores por derecho propio, la grandeza de España, los elegidos por los mayores contribuyentes y por el Rey. El duque de Gor clasificaba a los senadores en natos y nombrados por el Rey en número ilimitado y vitalicios, disminuyendo igualmente las atribuciones judiciales. Las citadas enmiendas se pueden encontrar en BERTELSEN, O. c., págs. 514-521.

78 La Constitución de 1845 se separa del régimen establecido en el artículo 15 de la Constitución de 1837, ampliándose consiguientemente la discrecionalidad del 
ilimitado ${ }^{79}$ y su elección corresponde al Monarca (art. 14), siendo el cargo vitalicio (art. 17) ${ }^{80}$, perteneciendo además a esta Cámara los hijos del Monarca y del heredero inmediato a sucederle siempre que hubiesen cumplido los veinticinco años (art. 18) ${ }^{81}$.

Para ser nombrado senador se necesitaba ser mayor de treinta años, pertenecer a unas categorías y cumplir unos requisitos pecuniarios que establecía el artículo $15^{82}$.

Rey, y por tanto su poder. Así lo explicita PAN-Montojo, GonZÁLEZ, J. L. ( «La Cámara de los intereses permanentes de la sociedad: el Senado español bajo la Constitución de 1845", en Revista de las Cortes Generales, n. ${ }^{\circ} 21$, 1990, págs. 59-83 [64 y 74], destacando su "subordinación al Gabinete» debido a su composición, consecuencia que se puede perfectamente generalizar a todo este periodo, a pesar de que el autor se refiere al Senado entre los años 1857-1862. Sigue la Constitución de 1845 en este punto a la Carta francesa de 1830 (reformada en diciembre de 1831) y al artículo 7 del Estatuto Real, olvidando los modelos belga y británico (electivo y hereditario respectivamente), como ya se observa en el Proyecto del Gobierno sobre la reforma de la Constitución. Así, la Cámara de Pares diseñada en el texto francés de 1830 se compone de pares elegidos por el Monarca en número ilimitado, si bien el mismo los podía nombrar vitalicios o hereditarios (art. 23), exigiéndose tener cumplidos los veinticinco años, no pudiendo participar en debate hasta los treinta; además conforman la Cámara alta los hijos del Rey por derecho propio (art. 18). La ley de 22 de diciembre de 1830 suprimió en Francia la pairía hereditaria y anuló los nombramientos realizados antes de 1830 . El artículo 68 de la propia Carta declaraba también nulos los nombramientos realizados por el depuesto Rey Carlos X.

79 Se vuelve al ejemplo francés de 1830, frente a la limitación del régimen de la Constitución de 1837 (art. 14) que establecía un número de senadores igual a las tres quintas partes del número de diputados, optándose así por un número ilimitado de miembros de la Cámara Alta, hecho que dotaba del mayor flexibilidad a las decisiones del Rey por si ello fuese necesario para el buen funcionamiento de las instituciones, tal y como ya ocurriese en el proyecto Istúriz.

${ }^{80}$ Siguiendo lo que ya estableciese el artículo 7 del Estatuto Real, se asume el mandato vitalicio (art. 17), discrepando así del artículo 19 de la Constitución de 1837, con la finalidad de lograr una mayor estabilidad e independencia de la Cámara. Los senadores que lo fueran "ex» artículo 18, lo siguen siendo mientras permanezcan en el consabido "status" dentro de la Familia Real. Como ya hemos indicado, el artículo 23 de la Carta francesa de 1830 establecía que los senadores eran elegidos por el Rey en número ilimitado. Vid. VERA SANTOS "La influencia del constitucionalismo francés...", o. c., pág. 172, nota 141).

81 Vid. nota 57 respecto a la presencia de miembros de la realeza tanto en los senados patrios como en los franceses de 1814 y 1830.

82 Frente al Proyecto Istúriz que no exigía pertenencia alguna a categorías, el artículo 15 del texto moderantista acoge el espíritu y la letra del artículo 3 del Estatuto Real, si bien establece mayor número de categorías y éstas resultan más concretas y restringidas. Así: A.- Presidentes de alguno de los Cuerpos colegisladores. B.- Senadores y Diputados admitidos tres veces en las Cortes. C.- Ministros de la 
Por último cabe destacar que el Senado de 1845 es el máximo exponente de las potestades judiciales de este órgano ya que, además de hacer suyas las recogidas en el artículo 40.4 del texto de 1837, las amplía, juzgando a los ministros cuando fuesen acusados por el Congreso

Corona. D.- Consejeros de Estado. E.- Arzobispos. F.- Obispos. G.- Grandes de España. H.-Capitanes generales del Ejército y Armada. I.- Tenientes generales del Ejército y Armada. J.- Embajadores. K.- Ministros plenipotenciarios. L.- Presidentes de Tribunales supremos. LL.- Ministros y Fiscales de los Tribunales supremos. M.-Títulos de Castilla. N.- Senadores, Diputados, Diputados provinciales y alcaldes de pueblos de más de treinta mil almas y Presidentes de Juntas o Tribunales de Comercio. La Comisión suprimió una última categoría: "Los que por servicios señalados hayan merecido una recompensa nacional decretada por una ley". Se alude a que se podrían conceder dichas recompensas con el único fin de conseguir que pudiesen ser nombrados senadores por el Monarca. En el Dictamen de la Comisión se puede leer lo siguiente: «Esas recompensas hechas en nombre de la Nación en tiempos como los nuestros, banderizos, no las tiene la comisión en grande estima, como quiera que no pocas veces sucede que son armas peligrosas puestas en manos de las parcialidades triunfantes"(SEVILLA ANDRES o. c., pág. 369). Estas categorías pasan en mayor o menor medida a las Constituciones de 1869 (art. 62) y 1876 (arts. 21 y 22). Las mismas pueden agruparse en: cargos políticos (Presidentes de Cuerpos colegisladores, senadores,...), altos cargos de la administración (Consejeros de Estado), la milicia, la diplomacia y la judicatura; en tercer lugar los grandes contribuyentes que hubiesen ocupado un cargo público, además de la nobleza y el alto clero. En la composición del Senado se observa así la "doctrina de las aristocracias naturales, levemente templada por esa presencia de la nobleza histórica y de la Iglesia (...) y fundida en el criterio doctrinario que exige a todos los senadores una elevada renta o una crecida cifra de contribución directa" (SÁNCHEZ AGESTA o. c., pág. 290). En cuanto a los requisitos económicos necesarios para la obtención de la senaduría, se exige a todas las categorías unos condicionamientos pecuniarios, tal y como se establecía en el régimen constitucional de 1837 (arts. 17 de la Constitución y 56 de la Ley electoral de 20 de junio de 1837). Por ello, el artículo 15 establece la necesidad para los Títulos de Castilla de gozar de sesenta mil reales de renta, pidiendo a los diputados y senadores que no hubiesen sido reelegidos dos veces, diputados provinciales, alcaldes de pueblos de más de treinta mil almas y a los Presidentes de Juntas o Tribunales de Comercio, que paguen con un año de antelación ocho mil reales de contribuciones directas.

Para las restantes categorías es necesario el disfrute de treinta mil reales de renta procedentes de bienes o de sueldos de los empleos que no pueden perderse sino por causa legalmente probada, o de jubilación, retiro o cesantía. El último párrafo de este mismo artículo 15 establece que «las condiciones para ser nombrado senador podrán variarse por ley", algo que aparece como redundancia en una Constitución flexible donde tanto el poder constituyente como el legislativo, son fruto del necesario acuerdo de las Cortes y del Rey. Este componente económico, que permite la presencia de las clases medias en las Cámaras, es el que permite calificar a las mismas como las máximas beneficiarias de la reforma de 1845 (Medina MuÑOZ, "La reforma..." o. c., págs. 86-91). 
de los Diputados, conociendo igualmente de los delitos graves contra la persona o la dignidad del Rey o contra la seguridad del Estado, juzgando también a los individuos de su seno en los casos y forma determinados por la ley (art. 19) ${ }^{83}$.

\section{LOS INTENTOS DE REFORMA DE LA CONSTITUCIÓN DE 1845}

\subsection{Los proyectos constitucionales de Bravo Murillo y el proyecto de Roncali}

En octubre de 1847 es llamado Narváez de nuevo a presidir el Consejo de Ministros, cargo que ocupa hasta enero de 1851 en que es sustituido por Bravo Murillo quién comienza una reforma del régimen constitucional intentando "legalizar y estabilizar» una dictadura del Ejecutivo $^{84}$. La reforma se presenta a las Cortes el dos de diciembre de 1852 para que se aprobase o rechazase en bloque. Los diputados se oponen tanto a esta forma de tramitación como al fondo que se trasluce de los proyectos de Bravo Murillo, por lo que éste disuelve las Cortes, publicando, junto al decreto de disolución, los proyectos de reforma (Gaceta del día 3 de diciembre), con el fin de que el pueblo pudiese

83 Ley de 8 de mayo de 1849, sobre jurisdicción del Senado (Diario de Sesiones del Congreso. Legislatura 1848-1849, n. ${ }^{\circ}$ 92, apéndice 2. ${ }^{\circ}$ Citada en SeVILLA ANDRÉs (o. c., págs. 387-394). Vid. al respecto GonZÁlez HERNÁNDEZ, E. La responsabilidad penal del Gobierno. Madrid: Centro de Estudios Políticos y Constitucionales, 2002, págs. 128 y ss, en las que se hace referencia al contenido de la citada ley de 1849 y también al Reglamento del Congreso de mayo de 1847, normativa que posibilitó la acusación, en 1851, del entonces Ministro de Hacienda Juan Bravo Murillo (que no prosperó) y el proceso a Esteban Collantes, a la sazón Ministro de Fomento, en 1859 (págs. 130-133).

${ }^{84}$ Los términos los tomamos de SÁnChez Agesta (o. c., pág. 303) y TorRes del MoRAL (o. c., pág. 88). Sin duda, esta tendencia a favor de un fortalecimiento del Ejecutivo viene influenciada por los sucesos revolucionarios europeos de $1848 \mathrm{y}$, sobre todo, por el golpe de estado de Luis Napoleón en diciembre de 1845, situación ésta que acabó con las ideas revolucionarias en Francia, tal y como destaca GonZÁLEZ HERNÁNDEZ (Breve historia ..., o. c., págs. 148-149). El proyecto de Constitución de Bravo Murillo - compuesto únicamente por cuarenta y dos artículos y uno adicional, sin inclusión de tabla de derechos, - iba acompañado de ocho leyes complementarias. A saber: de organización del Senado; de elecciones de Diputados a Cortes; de régimen de los Cuerpos colegisladores; de relaciones entre Cuerpos colegisladores; de seguridad de las personas; de seguridad de la propiedad; de orden público y, por último, de Grandezas y Títulos del Reino. Los textos de reforma de Bravo Murillo se encuentran en suplemento de la Gaceta de Madrid del día tres de diciembre de 1852. También en SEVILLA ANDRÉs, o. c., vol. I, págs. 395-426. 
mostrarle su apoyo en unas elecciones que no llegan a celebrarse pues Isabel II le destituye el 14 de diciembre, nombrando a Roncali en su puesto. Quedan pues sus textos de reforma en el limbo de los proyectos. Bravo Murillo vertebra su proyecto imbuido por las ideas de fortalecimiento del poder regio con predominio del ejecutivo y la consiguiente pérdida de atribuciones de las Cortes, de moderación de la participación política, de restricción de las libertades ${ }^{85} \mathrm{y}$, por último, de confesionalidad del Estado ${ }^{86}$.

Como decíamos, se dota a la Corona de amplísimos poderes ejecutivos e incluso legislativos en caso de urgencia, tal y como se observa en el artículo 20 del Proyecto de Constitución. El Rey es sagrado, inviolable e irresponsable, siendo responsables sus ministros (art. 19). Goza de iniciativa legislativa junto a las Cámaras (art. 4$)^{87}$. Suspende y convoca Cortes, disolviendo el Congreso de los Diputados (art. 22), debiendo en este último caso convocar Cortes en seis meses ${ }^{88}$. También, como rezaba el artículo 44 del texto moderantista de 1845 (siguiendo al artículo 46 de la Constitución de 1837), sanciona y promulga las leyes (art. 24) ${ }^{89}$. Los Presidentes y Vicepresidentes de las Cámaras eran nom-

85 En lo relativo a la parte dogmática, en el proyecto de Bravo Murillo se observa la desaparición de la libertad de prensa y de pensamiento, junto a las garantías procesales. Asimismo el artículo 11 del proyecto de ley de seguridad de las personas señalaba que el Gobierno, para conservar el orden o la seguridad pública, puede suspender los derechos que en ella se recogen, siempre que se anuncie dicha suspensión en la Gaceta y en los boletines de las provincias donde la suspensión fuese necesaria. Además, el artículo 1 del proyecto de ley de orden público permite que el Gobierno declare el denominado "estado preventivo", lo que traía consigo la suspensión de la Ley de seguridad. Por otra parte, el artículo 1 del proyecto de Constitución optaba de nuevo por el principio confesional con carácter excluyente de otros cultos.

${ }^{6}$ Características que destacan NúÑEz Rivero y Martínez SegarRa (o. c., págs. 136-137).

87 Tal y como indicaban también los textos de 1837 y 1845 (arts. 36 y 35, respectivamente) y se asume también en el artículo 15 de la Carta francesa de 1830, que, a su vez se separa de un artículo 16 del texto de 1814, en el que, como ya vimos, se dotaba de iniciativa exclusiva al Monarca.

88 Régimen que asume del artículo 26 de la Constitución española de 1845 (que a su vez es copia literal del también artículo 26 de su homónima de 1837) bien que difiere en el plazo para la convocatoria de Cortes una vez disuelto el Congreso (pasa de tres a seis meses, con lo que ello supone de refuerzo de los poderes del Ejecutivo). Los artículos 50 y 42 de las Cartas francesas meritadas establece como competencia regia la disolución de la Cámara baja (la Cámara de Pares gozaba de permanencia) si bien la convocatoria obligada se debía producir en un plazo de tres meses.

89 Sanción y promulgación regia que recogen también los artículos 22 y 18 de los textos galos de 1814 y 1830 . 
brados por el Rey (artículo 2 del proyecto de ley para el régimen de los Cuerpos colegisladores), quién también debía aprobar los Reglamentos de cada Cámara ${ }^{90}$, reuniéndose éstas a puerta cerrada (arts. 74 y 33 de la anteriormente citada norma) ${ }^{91}$. La celebración de matrimonio regio debía realizarse después de la aceptación por las Cortes de las estipulaciones y contratos previos (art. 28 del Proyecto de Constitución), siguiendo así el régimen establecido en 1845 (art. 47). La sucesión (arts. 29 a 34 del Proyecto de Bravo Murillo) sigue lo establecido en los artículos 50 a 55 de la Constitución de 1845. El Rey, además, se encontraba menos limitado por la necesidad de una ley autorizante, pues no la necesitaba para la admisión de tropas extranjeras en el territorio español (artículo 27 del Proyecto de Constitución en relación con el artículo 46 del texto de 1845).

El modelo de Bravo Murillo persevera en un bicameralismo perfecto (art. 9 del Proyecto de Constitución). Si bien la composición del Congreso es modificada con el fin de hacer entrar en él intereses más conservadores $^{92}$, la reforma más importante —nuevamente-, es la que se

90 El artículo 28 de la Constitución de 1845 postula la potestad reglamentaria de los Cuerpos Colegisladores, de igual manera que la reconocía el artículo 29 del texto liberal de 1837, bien que el Proyecto de Bravo Murillo se separa de dicho régimen. Por su parte, los artículos 28 y 30 del texto de 1845 asumían idéntico régimen al preferido por Bravo Murillo, alejándose del texto de 1837 que prefería dotar al Congreso de autonomía en sus nombramientos (art. 30), aunque la misma no se predicase respecto al Senado (art. 31). En cuanto a lo estatuido en los textos franceses, ha de indicarse que en 1814 se establecía que la Cámara de los Pares estuviese presidida por el Canciller de Francia o por un par nombrado por el Rey (art. 29), mientras que el Presidente de la Cámara de los Diputados de los Departamentos era elegido por el Rey entre una lista de cinco candidatos propuesta por la propia Cámara (art. 43). La Carta de 1830 recogía el contenido del artículo 29 citado en el número 25, mientras que su artículo 37 preveía la elección de Presidente de la Cámara baja por los propios diputados en la apertura de cada periodo de sesiones.

91 Se aparta así del régimen generalmente público que se propugna en España (art. 34 de la Constitución de 1845, muy similar en su literalidad al artículo 35 del texto de 1837). En el caso de Francia, el artículo 27 de la Carta de 1830 también aboga por la publicidad de las sesiones, olvidando los artículos 32 y 44 de su homónima de 1814 en los que se establecía el secreto de las sesiones en el caso de la Cámara alta y la publicidad referida a la Cámara de Diputados de los Departamentos, si bien, a solicitud de únicamente cinco de sus miembros, la sesión se celebraría en secreto.

92 Así el artículo 1 del proyecto de ley para las elecciones de los diputados a Cortes indicaba que habría ciento setenta y un diputados elegidos en distritos electorales; para ser elegible, decía el artículo 2, se necesitaba tener cumplidos treinta años, ser español y pagar tres mil reales de contribución directa o dos mil en determinados casos; para ser elector, el artículo 33 establecía la exigencia de estar situado entre los ciento cincuenta mayores contribuyentes. 
lleva a cabo en la composición del Senado. Ya el artículo 10 del Proyecto de Constitución indicaba que el Senado se compondría de tres clases de senadores: hereditarios, natos y vitalicios ${ }^{93}$ y el artículo 11 del Proyecto de Constitución se remitía a una ley especial donde se recogían las categorías de acceso ${ }^{94}$ y los requisitos para acceder al cargo de

93 "Los primeros eran los Grandes de España que pagasen 30.000 reales de contribuciones procedentes de bienes raíces propios vinculados: tal exigencia estimulaba la restauración de las vinculaciones que suponían la inalienabilidad de aquellos bienes y su transmisión obligada a quienes heredasen el título; de esta manera, al tiempo que la Grandeza, recibiría el patrimonio necesario al esplendor y decoro de la misma: un decoro y esplendor que se juzgaba necesario para que la presencia de la aristocracia de sangre en el Senado tuviera el debido prestigio e influencia. (...). La creación de los senadores natos y vitalicios no despertó reparos: pero, en cambio, se criticó duramente la senaduría hereditaria por atentar al espíritu de igualdad propio del siglo; por restituir a la nobleza un poder político que los nuevos tiempos, justamente, le habían arrebatado; por el peligro cierto de que las vinculaciones sustrajesen un volumen considerable de bienes a la libre circulación y comercio. Con todo, es interesante señalar que la Ley Constitucional de 1857 creó (...) una senaduría hereditaria muy parecida a la proyectada en 1852" (TOMAS VILLARROYA, o.c. págs. 73 y 74).

${ }_{94}$ Este proyecto de Ley de organización del Senado establece en su primer artículo que son senadores hereditarios los Grandes de España que lo sean por derecho propio, español de nacimiento o hijos de padres españoles, mayores de veinticinco años y pagar al menos treinta mil reales de contribución por bienes raíces propios vinculados. Son senadores natos (art. 4): A.- El Príncipe de Asturias. B.Los Infantes de España. C.- Los Cardenales españoles. D.- Los Capitanes generales del Ejército y de la Armada. E.- El Patriarca de las Indias y los Arzobispos. F.Los diez Tenientes generales del Ejército y el que lo fuere de la Armada. G.- Los seis Obispos más antiguos. Son senadores vitalicios (art. 5): A.- Ministros de la Corona con un año de ejercicio. B.-Presidentes de los Cuerpos colegisladores durante tres legislaturas. C.-Grandes de España. D.- Consejeros de Estado. E.- Vicepresidentes del Consejo Real y de Ultramar. F.- Embajadores con dos años de antigüedad en el cargo. G.- Ministros plenipotenciarios con tres años de permanencia. H.- Tenientes generales del Ejército y de la Armada. I.- Presidente del Tribunal Supremo de Justicia, del de Guerra y Marina y del de Cuentas del Reino. J.- Ministros y Fiscales de los mismos Tribunales, Asesor, Auditores y Fiscal del Tribunal de la Rota, Regente, Presidente de Sala y Fiscal de la Audiencia de Madrid y Decano del Tribunal especial de las Órdenes y Regentes de las demás Audiencias del reino que ostentasen el cargo tres años como mínimo. K.- Obispos. L.- Mariscales de campo y jefes de escuadra que hubiesen ocupado determinados cargos. LL.- Vocales de los Consejos Real y de Ultramar con tres años en el cargo. M.-Títulos del Reino. N.- Máximos contribuyentes que hayan sido además diputados, senadores, diputados provinciales, alcaldes de pueblos de mas de treinta mil almas o presidentes de juntas o tribunales de comercio. Debemos hacer constar que, excepto los apartados $E, L$ y $L L$, las categorías restantes referentes a los senadores vitalicios aparecen ya en 1845 , aunque se introducen ciertos requisitos referidos sobre todo a la 
senador ${ }^{95}$. Dicha ley no era sino el proyecto de ley sobre la organización del Senado, muy influenciada por la enmienda del marqués de Montevirgen ${ }^{96}$.

Aunque las Cámaras siguen disponiendo junto con el Monarca de potestad legislativa, gozando igualmente de iniciativa en este campo (arts. 3 y 4 del Proyecto de Constitución) ${ }^{97}$, el artículo 20.2 atribuye a la Corona, en casos de urgencia, la potestad de anticipar disposiciones legislativas, oyendo previamente a los altos cuerpos de la Administración y dando posteriormente cuenta a las Cortes en la legislatura inmediata. Como ya hemos indicado, las sesiones se celebrarían a puerta cerrada (art. 33 del proyecto de ley para el régimen de los cuerpos colegisladores).

Como el régimen esbozado por Bravo Murillo se configuraba como un bicameralismo perfecto (art. 9), las competencias del Senado corren parejas a las de la Cámara Baja ${ }^{98}$. Desaparecen las potestades de autonomía reglamentaria que reconocía el artículo 28 de la Constitución de 1845 , ya que, en virtud del artículo 74 del proyecto de ley de relaciones entre los Cuerpos colegisladores, el Reglamento de cada Cuerpo debe someterse una vez realizado por el Presidente de la Cámara, a la aprobación del Monarca, quién, y como también hemos ya indicado, nombra a aquél y a los Vicepresidentes (art. 2 del citado proyecto). Se incluye, siguiendo el modelo británico, las tres lecturas de cada proyecto

permanencia en el cargo. El número de los mismos aparece como indefinido, lo que permitía mayor capacidad de reacción por parte del Rey.

${ }_{95}$ El proyecto de ley de organización del Senado prescribe diferentes edades para cada tipo de senador. Así para los senadores natos, se exige la tenencia de catorce años para el Príncipe de Asturias y de veinte para los Infantes de España. Para ser senador designado por el Rey se requiere la edad de cuarenta años (arts. 1, 4 y 5 del citado proyecto). Por tanto lo establecido en el artículo 12 del Proyecto de Constitución sobre la edad genérica para alcanzar la senaduría a los veinticinco años, decae respecto a las edades referentes al Príncipe de Asturias y a los Infantes de España, siguiendo vinculando a los hijos del heredero inmediato a la Corona, que deben cumplir los veinticinco años para acceder al cargo.

96 Vid. nota 77.

97 Como indicamos en la nota 87 , los artículos 36 y 35 de las Constituciones de 1837 y 1845 también asumen esta iniciativa legislativa compartida. Recordamos nuevamente que el artículo 16 de la Carta francesa de 1814 dotaba al Monarca de iniciativa legislativa exclusiva, si bien en 1830, la misma ya es compartida con las Cámaras (art. 15).

98 Idéntico reparto competencial se daba también en las Cartas francesas tantas veces referidas, con las excepciones sabidas de la tramitación de la ley de presupuestos y las tareas de juicio político 
para su aprobación definitiva (art. 40): sobre espíritu y oportunidad; sobre articulado y, finalmente, se procede a la votación ${ }^{99}$.

En lo referente a las atribuciones judiciales de las Cámaras, el artículo 13 del Proyecto de Constitución es muy similar al 19 de la Constitución de 1845. Su diferencia estriba fundamentalmente en que, para que el Senado pueda conocer por delitos graves contra el Rey o la seguridad del Estado, se especifica que únicamente el Gobierno se encuentra legitimado para instar la causa ${ }^{100}$.

Una vez que Bravo Murillo pierde la confianza de la Reina, ésta nombra a Federico Roncali Presidente del Consejo de Ministros, quién, ante lo sucedido a su antecesor, deja en el olvido una reforma constitucional radical, pero sí considera que se debe "no solo mantener en toda su pureza los principios que sirven de base al régimen constitucional vigente, sino asegurarlos y fortalecerlos con nuevos elementos de vida y estabilidad ${ }^{101}$.

Así, las variaciones que se producen son mínimas. Además de la diferente composición senatorial que sigue la propuesta por Bravo Murillo, deroga también los artículos $28,45,5 .^{\circ}$ y 54 , sobre cuestiones tales como la discusión presupuestaria o la exclusión por ley de personas incapaces a suceder al Trono ${ }^{102}$.

99 Tomas Villarroya (o. c., pág. 75) indica ésta medida, junto a la posible legislación de urgencia por el Monarca y la permanencia del Presupuesto (arts. 20 y 6 del Proyecto de Constitución), como ejemplos de la reducción competencial de las funciones del Parlamento.

100 La ley de 8 de mayo de 1849 ya exigía la necesidad de un Real Decreto del Consejo de Ministros respecto a lo establecido en la mencionada disposición de la Constitución de 1845. El artículo 1 de la norma de 1849 establece que "corresponde al Senado como tribunal: (...) 2. ${ }^{\circ}$ Conocer en virtud de Real decreto acordado en Consejo de Ministros de las causas sobre delitos graves contra la persona o dignidad del Rey, o contra la seguridad interior o exterior del Estado" (ley citada en SEVILLA ANDRÉS, o. c. , vol.l, págs. 387-394, Vid. al respecto nota 83.

101 Tal y como se pone de manifiesto en el «Proyecto de ley para la reforma de la Constitución» que presenta a las Cortes el día 29 de marzo de 1853. Se puede encontrar en SeviLLA ANDRÉs, o. c. , vol. I, págs. 427-432.

102 La Cámara Alta, salvo en lo que a continuación reflejamos, mantiene lo dispuesto en 1845, excepto en su composición, que sigue al Proyecto de Constitución de Bravo Murillo, matizándolo en los siguientes aspectos: a) respecto a las categorías que establecía el artículo 4 del proyecto sobre organización del Senado, no pueden ser senadores por derecho propio ni los Tenientes generales ni los Obispos mas antiguos (nueva redacción del artículo 15); b) el nuevo artículo 16 prescribía una única categoría de acceso a la senaduría hereditaria, ya que sólo los Grandes de España lo pueden ser, siempre que el Rey les otorgue especialmente esa gracia y que po- 


\subsection{La Constitución "non nata» de 1856, el Acta adicional de 1856 y la ley de reforma de 1857}

Depuesto Bravo Murillo y tras los breves gobiernos de Roncali y Lersundi, preside el Consejo de Ministros Sartorius, Conde de San Luis (septiembre de 1853), ante cuya política se van a unir a los progresistas ciertos sectores moderados que van a protagonizar toda una serie de movimientos insurreccionales cuya máxima expresión es la conspiración militar de los generales Dulce y O'Donnell conocida por "la vicalvarada»(30 de junio de 1854), seguida de la redacción del Manifiesto del Manzanares en julio del mismo año ${ }^{103}$, mes que va a ser testigo de numerosos levantamientos en ciudades como Barcelona, Valladolid o Zaragoza, trasladándose a la capital del reino el día 17, ante lo que Sartorius dimite y Espartero es Ilamado por Isabel II a presidir un Consejo de Ministros en el que O'Donnell aparece como Ministro de la Guerra.

Acto seguido se convocan Cortes constituyentes unicamerales en circunscripciones provinciales, siguiendo para ello lo prescrito en la ley electoral de $1837^{104}$. Después de su elaboración en Comisión, debate en Cortes y devolución para que se reelaborasen las bases que informarían el texto articulado, el 14 de diciembre de 1855 se terminó de

sean una renta de doscientos cuarenta mil reales procedentes de bienes vinculados (el Proyecto de Bravo Murillo permitía serlo también a los Títulos de Castilla y la renta exigida era de treinta mil reales, tal y como se desprende de los artículos 1 y 2 del proyecto de ley de organización del Senado); c) en cuanto a los miembros de mandato vitalicio, cuyo número es ilimitado, se repiten en una u otra medida las categorías establecidas en el artículo 5 del mencionado proyecto que intentase aprobar Bravo Murillo, salvo excepciones mínimas como la desaparición en el nuevo artículo 17 de algunas de las categorías reflejadas en el mencionado precepto. No se exigen requisitos de permanencia en el cargo, siguiéndose así el modelo de 1845, como también ocurre a la hora de fijar la edad de acceso a la senaduría, siendo ésta de treinta años tal y como reflejaba el artículo 15 de la citada Constitución.

103 Texto en ARTOLA, M. Partidos y programas políticos. Madrid: Alianza editorial, vol. II. 1991, pág. 46. Se considera que este manifiesto, redactado por el joven Cánovas del Castillo, es una invitación a los sectores más progresistas a sumarse a la insurrección. Así se aluden ciertos temas como la mejora de las leyes electorales y de imprenta, rebajar los impuestos o disminuir la centralización.

104 Como señala KIERNAN en La revolución de 1854 en España. Madrid: Aguilar. 1970, pág. 109, esta Cámara constituyente de 1854 aparece como "la más brillante y notable de toda la historia de España». Dicha Cámara se constituye el 28 de noviembre y dos días más tarde aprueba una resolución a favor de la Corona que, a pesar de ser ampliamente ganada, constata que existe una veintena de miembros que no optan por la Monarquía constitucional que debía encarnar Isabel II. 
discutir un texto que, volviendo sus ojos al texto transaccional de $1837^{105}$, no se llegó a publicar como tal, en espera de la realización de unas leyes orgánicas que el artículo 92 del proyecto constitucional consideraba como "parte integrante de la Constitución»" ${ }^{106}$.

Esta Constitución "non nata» ${ }^{107}$ es de extensión intermedia (92 artículos repartidos en 15 títulos, aunque vía artículo 92, ampliaría su

105 Por todos, TorRes DEL Moral, o. c., pág. 90. A lo expuesto respecto al texto de 1837 nos remitimos, así como a su cotejo con el moderantismo de la Constitución de 1845.

106 Estas leyes orgánicas serían, como señala el mencionado artículo, la ley electoral, la de relaciones entre los Cuerpos colegisladores, la ley del Consejo de Estado, la referente al gobierno y administración provincial y municipal, la de organización de los tribunales, la de imprenta y la de la milicia nacional. Esta espera determinó el carácter de "no nacida» ante las maniobras del general O’Donnell para deshacerse de Espartero y darle un rumbo más moderado a la política gubernamental, terminando de esta forma con una revolución que él mismo había ayudado a nacer dos años atrás, y utilizando para ello una pírrica victoria tanto política (su enfrentamiento con el Ministro de Gobernación, el progresista Escosura, conlleva que ambos presenten la dimisión a la Reina, quien acepta la de éste, hecho ante el que Espartero dimite solidariamente, y O'Donnell es llamado para formar gobierno), como militar (sobre unas insignificantes insurrecciones que se producen por el hecho anterior). Así decae no sólo el texto progresista sino también el bienio que es conocido con dicho nombre. Muy detallado respecto al bienio progresista, en su óptica o vertiente parlamentaria y política, el artículo de SEVILLA ANDRÉS "La constituyente de 1854", en Revista de Estudios Políticos, 1959, págs. 129-165: desde "la vicalvarada" a su juicio crítico con la actuación de dichas Cortes, realiza un excelente discurrir por los acontecimientos (pronunciamientos, creación de partidos, desamortización, discusiones en el Senado sobre la organización de la milicia nacional), hasta llegar a un final pronosticado, calificando a estas Cortes como "un paréntesis poco grato en la Historia de España», que, citando a Canalejas "dejó huella poco fecunda en la vida patria» (pág. 163). Destaca esta postura frente a otras como la de Clavero (o. c., pág. 85) en la que, refiriéndose a la situación general de esta época destaca que «igual que se producen regresiones, vienen impulsos en la historia constitucional», destacando lo sugerente de estas reformas que se intentan en este periodo progresista.

107 Para llevar a cabo el estudio de este período histórico, seguimos el texto (que no llegó a publicarse ni a promulgarse) que recoge SEVILLA ANDRÉs (o. c. , págs. 463-475). Incorpora también las enmiendas que se admitieron durante el debate. Para la elaboración del texto se sigue una tramitación similar a la que se produjo para la realización de la Constitución de 1837. Así, una Comisión realiza unas bases que luego son aprobadas por las Cortes para posteriormente construir un proyecto de Constitución. De cualquier forma, en este caso las bases son mucho más amplias. El Dictamen de la mayoría de la Comisión y los votos particulares, junto al proyecto de ley de bases de la Constitución de 1856 se pueden encontrar en SEVILLA ANDRÉs (o. c., pág. 433 y ss). 
extensión) y de carácter rígido (arts. 87 a 91) ${ }^{108}$. Asume como principios: a) la soberanía nacional -no ya en el preámbulo como en 1837, sino en el primero de sus artículos ${ }^{109}$-; b) la colaboración entre poderes, con un articulado que indica las tareas básicas legislativas, ejecutivas y judiciales a órganos diferentes ${ }^{110}$ (arts. 15, 49 y 67), bien que corregidas en un sentido parlamentarista debido a la compatibilidad de cargos parlamentarios y ministeriales (art. 66), el derecho de disolución regia del Congreso de los Diputados (art. 28) ${ }^{111}$ y el derecho de veto temporal por una legislatura (art. 40) ${ }^{112}$; c) como defensa de las libertades, debemos mencionar que su parte dogmática restablece la libertad de pensamiento y la calificación por los jurados de los delitos de imprenta (art. 3) ${ }^{113}$; vuelve también a introducir — junto a la de códigos-, la unidad de fueros (art. 5) ${ }^{114}$, asume el principio de igualdad para el acceso a los cargos públicos, en virtud de la valoración de los principios de mérito y competencia (art. 6) ${ }^{115}$, y procede a la abolición de la pena de muerte por delitos políticos (art. 11); y d) no obstante, lo más destacable, por la

108 Se sigue un procedimiento de reforma conocido como de doble aprobación: la iniciativa pertenece a las Cortes con el Rey, indicando los artículos a reformar (art. 87). El Rey disuelve a continuación las Cámaras y convoca Cortes que se han de reunir en un plazo de dos meses, siendo constituyentes respecto a la materia explicitada (arts. 88 y 89). Estas nuevas Cortes constituyentes no pueden adoptar acuerdos si no se encuentran reunidos dos terceras partes de los miembros que las componen (art. 90). El artículo 91 indicaba que, una vez acordada la reforma por las dos Cámaras, las mismas continúan como ordinarias. A nuestros efectos, obsérvese la presencia del Rey como sujeto que comparte la iniciativa de reforma.

109 De "origen popular» la califica TOMÁs VILLARROYA (o. c., pág. 77), que también destaca su carácter completo al recoger la parte dogmática. La aparición de la soberanía popular en el articulado, entronca con el primer liberalismo español, plasmado en el artículo 3 de la Constitución de 1812, bien que, como destaca TORRES DEL Moral (o. c., pág. 91) "no extrae su consecuencia obligada: el sufragio universal».

110 Vuelve a la denominación, y al concepto, de Poder Judicial del texto de 1837 (Tí́tulo X).

111 Compatibilidad entre los cargos de ministro y miembro de las Cámaras, junto al derecho de disolución regia que, como sabemos, recogían los textos españoles de 1837 (art. 62) y 1845 (art. 65), así como los franceses de 1814 (art. 54) y 1830 (art. 46).

112 Vid., junto a las referencias que posteriormente realizamos, lo explicitado en notas 32 y 73, en las que observamos el articulado de los textos de 1837 y 1845, junto a las referencias relativas a los textos franceses estudiados.

113 Siguiendo el artículo 2 de la Constitución de 1837. Vid. nota 27 sobre la evolución de la regulación de este derecho en nuestro constitucionalismo.

114 Nuevamente vuelve hacia el texto constitucional liberal de 1837, en su artículo 4.

115 Principios que también son reconocidos como tales en los artículos 5 respectivos de los textos españoles de 1837 y 1845. 
discusión que conllevó, fue el derecho a la libertad de conciencia y de cultos que recoge el artículo $14^{116}$, redacción que supuso la ruptura de relaciones diplomáticas con la Santa Sede al considerar esta última que se violaba el Concordato firmado en $1851^{117}$.

Si bien la Corona, como venía siendo habitual hasta la fecha, seguía siendo sagrada, inviolable e irresponsable (art. 48), carecía de prerrogativas respecto a la composición, organización y funcionamiento de las Cámaras ${ }^{118}$, y el artículo 53 ampliaba la necesidad de autorización especial a aspectos como la amnistía o la enajenación de bienes y de partes del territorio. Por otro lado, los ministros podían pertenecer a cualquiera de las Cámaras (art. 66) y estaban obligados a refrendar los actos del Monarca (art. 65) ${ }^{119}$.

Respecto al poder legislativo, el artículo 16 opta por un modelo bicameral. Al Congreso de los Diputados le dedica el texto "non nato" los artículos 24 a 27, estableciendo la elección directa en distritos provinciales en número de un diputado por cada cincuenta mil almas, requiriéndose los veinticinco años, ser varón y seglar, además de otros requisitos que estableciese la Ley electoral, siendo su mandato por tres años, pudiendo ser reelegidos. El artículo 29 indicaba que las Cortes debían reunirse al menos cuatro meses al año, para evitar así injerencias regias $^{120}$.

Por otra parte, aparece un Senado cuya composición, en avanzado sentido liberal, no será siquiera recogida en el texto progresista de 1869. Así el Senado es regulado en el Título III (arts. 17 a 23) estable-

116 Artículo cuyo precedente, como no, se encuentra en el artículo 11 de la Constitución española de 1837 y que se separa el artículo 11 de la Constitución de 1845, asumiendo el régimen francés de 1830 (arts. 5 y 6) que, a su vez, se distingue de la confesionalidad de la Carta de 1814 (art. 6).

117 Así lo indican NúÑez Rivero y Martínez Segarra (o. c., págs. 137-138).

118 Volviendo a lo previsto en los textos de 1837 y 1845 y separándose así del proyecto de Bravo Murillo. Vid. nota 90 en la que aludimos a la regulación referida en los textos españoles anteriores y en los franceses que estudiamos.

119 Como señala la doctrina, las similitudes con la Constitución de 1837 eran evidentes en cuanto a la configuración de los poderes de la Corona, aunque en las discusiones que se plantean para la elaboración de esta Constitución se observa un espíritu distinto. Incluso se llega a discutir la institución de la Monarquía (sesión del 30 de noviembre) y, citando al marqués de Albaída, "cuando estas cosas se discuten, están heridas de muerte, no pueden durar mucho tiempo; la discusión las mata" (TomAs VILLARROYA o. c., pág. 78). Y es que no es sólo el "espíritu» lo que se pone en duda.

120 Es evidente la influencia recibida por los artículos 21 a 25 del texto de 1837. 
ciendo que sus miembros van a ser elegidos por los mismos electores y de igual manera a la establecida para las elecciones al Congreso (art. 18), dejando, por tanto, de lado el sistema de ternas que se establecía en el artículo 15 del texto de $1837^{121}$. El número de senadores es igual a las tres quintas partes del existente en el Congreso de los Diputados ${ }^{122}$, correspondiendo un mínimo de un senador por provincia, incrementándose esta cantidad en virtud de criterios de población (art. 19), tal y como se recogía en el artículo 16 de la Constitución de 1837. Se renuevan parcialmente en orden a la antigüedad en el cargo por cuartas partes (en 1837 se procedía a la renovación por terceras partes - art. 19-), cada vez que expirase el mandato del Congreso de los Diputados o este fuese disuelto (art. 22) ${ }^{123}$.

El artículo 17 de la Constitución de 1837 es recogido en el 20 de la "non nata", que explicita los requisitos para acceder a la senaduría (ser español y mayor de cuarenta años), aunque ahora no se remite a una ley electoral que completase los requisitos económicos, sino que estos vienen recogidos en el ya citado precepto, exigiéndose el pago con dos años de antelación de tres mil reales de contribución directa, tener treinta mil reales de renta procedentes de bienes propios, disfrutar de idéntica cantidad de sueldo de un empleo que no se pueda perder legalmente sin previa formación de causa o, por último, percibir o tener declarado derecho a percibir igualmente treinta mil reales anuales por jubilación, retiro o cesantía. Al igual que en los artículos 20 y 18 de las Constituciones de 1837 y 1845, este texto "non nato" aboga por la permisión del acceso a la senaduría a los veinticinco años para los hijos del Rey y del sucesor inmediato a la Corona por razones de consanguinidad (art. 23).

Como hemos indicado, tanto el Congreso de los Diputados como el Senado de la "non nata», participan, junto con el Rey, del poder legislativo (art. 15). El artículo 37 dota de iniciativa legislativa a las Cámaras

121 Ni que decir tiene que tampoco aboga por el Senado, de clara vinculación regia, que prevé el texto de 1845, en sus artículos 14 a 18, ni tampoco por los modelos franceses citados.

122 Vid. art. 17 que recoge lo dispuesto en el art. 14 de la Constitución de 1837.

123 Por tanto, al renovarse por cuartas partes cada vez que se elijan diputados o se disuelva dicha Cámara, en orden a su antigüedad (art. 12), el mandato puede durar hasta doce años (cuatro veces más que el de los diputados), cabiendo la reelección. El mandato es más amplio que en 1837 porque en dicha Constitución (art. 19), se producía la renovación por terceras partes (excepcionamos de nuevo a los senadores por derecho propio en virtud de las relaciones de consanguinidad con el Monarca). 
junto al Rey y el 40 aludía también al derecho de veto ${ }^{124}$ (arts. 36 y 39 de la Constitución de 1837). Las Cortes reciben el juramento del Rey sucesor o Regente, resuelve dudas de hecho o de derecho, etc.(art. 41). Asimismo se restablece la primacía del Congreso de los Diputados en las decisiones de carácter presupuestario, tal y como se observa en el artículo 38, que hace suyo lo establecido en el texto de 1837 en su artículo 37. En el artículo 79 se desarrollan los plazos a cumplir en esta función presupuestaria. El artículo 31 restablecía el 29 de la Constitución de 1837, dotando a cada Cámara de potestad estatutaria. Además el artículo 32 establece la potestad de las Cámaras para elegir los miembros de la Mesa, frente al régimen establecido en el artículo 31 de 1837 que anulaba esa posibilidad referida a la Cámara Alta ${ }^{125}$.

Finalmente, el artículo 41.4 reseña que el Senado juzga a los ministros a los que previamente debe acusar el Congreso, siendo idéntico a lo establecido en el artículo 40.4 del texto de $1837^{126}$.

Como indicamos anteriormente, esta Constitución "non nata» decae porque O'Donnell disuelve las Cortes constituyentes el día 2 de septiembre de 1856 restableciendo la Constitución de 1845 junto a un Acta Adicional ${ }^{127}$ que es considerada como un punto de equilibrio entre el texto moderado de 1845 y el proyecto más progresista de $1856^{128}$.

${ }^{124}$ Régimen similar al veto previsto en el artículo 17 de la Carta de 1830 . Respecto a la iniciativa legislativa compartida con el Monarca, vid. notas 72 y 87.

125 Vid. nota 118 en cuanto a la regulación sobre la cuestión en los textos nacionales y franceses de referencia.

126 Por tanto disminuyen desmesuradamente sus atribuciones judiciales respecto a las que se establecieron en los artículos 19 y 13 de la Constitución de 1845 y del Proyecto de Bravo Murillo respectivamente. Vid. igualmente al respecto de esta cuestión notas 83 y 100.

127 Real Decreto restableciendo la Constitución de 1845 y Acta Adicional en La Gaceta de Madrid de 16 de septiembre de 1856, pág. 1. Recoge igualmente la Exposición de Motivos a la Reina. También en SeVILLA AndRÉs, o.c., págs. 483-491. Este Acta Adicional está compuesta por dieciséis artículos y es de dudosa legalidad, al no elaborarse mediante un acuerdo entre las Cortes y el Rey, tal y como se derivaba de la Constitución de 1845. Así por ejemplo lo observa Narváez cuando deroga el Acta Adicional, también por Real Decreto de 14 de octubre de 1856 (SEVILLA ANDRÉs, o. C., págs. 493-494, en concreto 493 «in fine»).

128 Así, como el texto "non nato", se introduce el jurado para calificar los delitos de imprenta (art. 1) o se establece un período mínimo de reunión de las Cortes de cuatro meses al año (art. 6). Respecto al Senado, la modificación más importante venía reflejada en un artículo tercero donde se establecía que "la primera creación de senadores no podrá exceder de ciento cuarenta. Hecha ésta, sólo podrá el Rey nombrar senadores cuando estén abiertas las Cortes». Por tanto se observan pocos 
El Acta Adicional de septiembre de 1856 se publicó, aunque no llegó a aplicarse, ya que el 12 de octubre de 1856, nombrado Narváez Presidente del Consejo de Ministros, deroga la misma y restablece la Constitución de 1845 sin modificaciones, convocando unas elecciones que van a dar lugar a unas Cortes donde prevalece la ideología moderada y que van a ser las encargadas de realizar una nueva reforma ${ }^{129}$ de la Constitución de 1845, datada el 17 de julio de 1857 y centrada casi exclusivamente en aspectos referidos al Senado. De esta reforma que lleva a cabo Narváez, merece destacarse que los senadores (en número ilimitado, lo que amplía la posible injerencia del Rey con el nombramiento de "hornadas de pares») pueden serlo tanto por derecho propio, como designados por el Rey, o hereditarios (arts. 14, 15 y 17) (130. $^{\text {. }}$

cambios en cuanto a la composición de la Alta Cámara, pues los senadores, como en el texto de 1845, siguen siendo por derecho propio y designados por el Monarca de entre ciertas categorías con un mandato vitalicio. Por otra parte se restringen ciertas actuaciones regias, debiendo ser autorizado por una ley especial para conceder indultos generales o amnistías y para enajenar en todo o en parte el patrimonio de la Corona (art. 9). Igualmente se exige autorización previa de las Cortes para el matrimonio regio (art. 10). En lo tocante a cuestiones presupuestarias, los artículos 7 y 15 prevén la prórroga de los mismos en caso de disconformidad entre ambas Cámaras y la obligatoriedad del Gobierno de presentar las cuentas del penúltimo año y el presupuesto para el año próximo en los ocho días siguientes a la apertura de Cortes.

129 La reforma de Narváez consistió sobre todo, tal y como figura en la Exposición del Gobierno a las Cortes y asume el Dictamen de la Comisión del Senado, en exigir mayores requisitos para ser nombrado senador (art. 15), ubicar en el Senado los altos puestos de la Iglesia y el Estado (art. 14) e incluir la senaduría hereditaria (art. 17), aludiendo a la necesidad de que la Corona debe sustentarse en instituciones que también asuman el principio hereditario en el cual ella se basa. Como consecuencia se instaura la vinculación de bienes a favor del mantenimiento de la senaduría hereditaria (art. 18), aunque es algo potestativo y no obligatorio, diferenciándose así de lo establecido tanto en el artículo 6 del proyecto de Bravo MuriIlo sobre Grandezas y Títulos del Reino como en el artículo 16 del proyecto de Roncali. Como destaca la doctrina, esta reforma "se refiere esencialmente a la composición del Senado, en la que sigue un esquema paralelo al proyecto de Bravo Murillo, distinguiendo entre senadores natos, reduciéndose el número de Obispos y Generales del Proyecto de Bravo Murillo; senadores hereditarios, que son los Grandes de España que gozan de una determinada renta y senadores designados por el Rey" (Fraile Clivilles o. c., pág. 269). Merino Merchán, o. c., pág. 269), considera que "sólo sirvió para consagrar de nuevo, contra el viento y marea de la época, el Senado aristocrático, al tiempo que el artículo 18 permitía el anacronismo que los Grandes de España pudiesen constituir nuevos mayorazgos». Vid. también CLAVERO (o. c., pág. 95).

130 Siguen un modelo clasificatorio que recibe influencias del Estatuto Real (arts. 4,5 y 6), de la enmienda del marqués de Montevirgen, y de los artículos 10 y 14 de 
La reforma de Narváez continuó vigente hasta que, el 20 de abril de 1864 (Gaceta del 22), bajo el gabinete de Alejandro Mon, se deroga la reforma de $1857^{131}$, lo cual conlleva una vuelta al régimen de 1845, meses antes de la caída de la Monarquía borbónica en 1868.

\section{CONCLUSIONES}

De lo expuesto con anterioridad y de manera sumaria, podemos concluir que en el periodo de "reafirmación" del constitucionalismo en España, en esta fase de "consolidación" democrática, la influencia del constitucionalismo francés es evidente.

El periodo isabelino nos sirve como encuadre político de una fase constitucional moderantista, de un liberalismo doctrinario que, apostando por la teoría de la Constitución interna, partía del reconocimiento histórico de dos principios básicos que articulan la realidad política española: el principio monárquico y las Cortes. De esta previa realidad se desprenderá la soberanía compartida entre el Rey y las Cortes, junto a un régimen de colaboración entre los poderes.

Las Constituciones de 1837 y 1845, consideramos, rompen, en primer término, con el liberalismo revolucionario gaditano (así, hemos calificado a la Constitución de 1837 no como reforma del texto de 1812 sino, antes bien, como un nuevo texto constitucional) y, en segundo lugar, atemperan posteriormente ese liberalismo transaccional a la co-

los proyectos de Bravo Murillo y Roncali respectivamente. El artículo 16 señala con carácter general la edad de treinta años para alcanzar la senaduría, exceptuándose los hijos del Rey y del inmediato sucesor a la Corona a los que se les exige la edad de veinticinco años (art. 14), requisito temporal que coincide con el prescrito en la Constitución de 1845. En cuanto a la duración de la pairía, el artículo 17 señala que, respecto a los Grandes de España reflejados en el artículo 14, el cargo es hereditario, siendo vitalicio para todos los demás. Obviamente, el régimen temporal de los senadores que lo son por derecho propio depende del mantenimiento del cargo matriz que da lugar al mantenimiento de la senaduría.

131 El restablecimiento de la Constitución de 1845 que lleva acabo Mon con Cánovas del Castillo en el Ministerio de la Gobernación, se puede encontrar en SÁINZ DE VARANDA, R. Colección de leyes fundamentales. Zaragoza: Acribia, 1957, pág. 271. Los senadores vuelven a ser nombrados por el Rey de entre categorías, aunque, a través de la disposición transitoria de dicha ley de derogación, se admiten como senadores a los Grandes de España que en 1857 eran hereditarios si lo solicitan en el plazo de un año, necesitando no ser súbditos de otra potencia, la posesión de una renta de doscientos mil reales procedente de bienes inmuebles o de derechos que gocen de idéntica consideración. 
rriente moderantista europea y española (es decir, que la Constitución de 1845 supone una reforma de la anterior optando por un sentido más moderado).

Ni que decir tiene que, llegados a este punto, y como se observa en el trabajo, el moderantismo francés de las Cartas de 1814 y de 1830 se ha visto reflejado en nuestros textos isabelinos y en los intentos de reforma que sufriera la Constitución de 1845.

Este sentir moderado nos sitúa ante Constituciones breves - que así se consideran las Cartas francesas de 1814 y 1830 y nuestros textos patrios-, que lo son tanto porque regulan aquello "estrictamente necesario" - huyendo de las grandes proclamas del primer liberalismo (y los ejemplos gaditano en España y de la Constitución francesa de 1791 son evidentes), buscando la concreción, la practicidad normativa que caracteriza esta nueva época-, como también para permitir que la Corona ostente una situación de paridad con el otro órgano dotado de legitimidad: las Cámaras.

Así, en el ámbito dogmático, aparecen por vez primera en España una sistematización de los derechos, procediendo a un reconocimiento de los mismos y posponiendo su desarrollo al legislador ordinario, dotando al sistema de la necesaria elasticidad, amén de que el sentir moderantista, basado en el binomio reconocimiento-sanción, se aleja de proclamaciones casi taumatúrgicas del revolucionario liberalismo de la Declaración de derechos del hombre y del ciudadano.

Esta realidad constitucional nos lleva hasta un concepto básico para entender el moderantismo reinante: la soberanía compartida entre el Rey y las Cortes, tal y como se observa en este trabajo en el que se predica la misma respecto a los textos de 1837 y 1845, así como del francés de 1830. Un concepto que viene vinculado a la consolidación de un bicameralismo perfecto en el ámbito funcional entre una Cámara baja electiva por sufragio censitario y una Cámara senatorial moderadora, tanto por su composición como por gozar de unas competencias similares a las de la Cámara electiva, definiendo un sistema bicameral perfecto; este Senado debería actuar como muro de contención ante posibles "avalanchas" de jacobinismo de la Cámara de representantes populares. Se constituye el Senado, precisamente y como se expone en este trabajo, en una de las cuestiones más polémicas, no tanto en cuanto a su existencia, sino respecto, sobre todo, a su composición. EI monocameralismo propio del liberalismo radical, protagonista de la etapa revolucionaria francesa y del inicio gaditano de nuestro constitucionalismo es así abandonado. 
Igualmente, olvidándose del primer y revolucionario liberalismo, la rígida separación de poderes deja paso a una colaboración entre los mismos; a una colaboración a la que el propio Montesquieu aludía en su obra más célebre, considerándola como signo de la anhelada moderación política. Nuevamente, los textos españoles y francés se nutren de esta idea, mediante la que se logra potenciar los poderes de una Corona que colabora en el ámbito legislativo de una manera muy intensa, confirmándose un régimen parlamentarista que tuvo sus precedentes en España durante la vigencia del Estatuto Real y en Francia con la Carta de 1814, tal y como adujimos en otro estudio.

El nombramiento por el Monarca de ministros que gocen de la mayoría de la Cámara baja; la disolución de la misma por el Rey ante posibles situaciones de enfrentamiento con el Gobierno, o la compatibilidad del cargo ministerial con el mandato parlamentario, son cuestiones claves que ejemplifican esa colaboración entre los poderes que, como hemos adelantado, surge de una soberanía compartida entre el Rey y las Cortes que dota de flexibilidad a los textos constitucionales.

Quizás estas conclusiones, así redactadas, rompen con una doctrina preconcebida y latente de "acción-reacción», de observar una "ley del péndulo" que podría explicar nuestro constitucionalismo histórico, al igual que el francés. Esta teoría de los extremos puede ser eficaz, consideramos, dentro de cada fase político-constitucional; si aparece enmarcada dentro de un modelo general que dota de sentido a las postreras peculiaridades que se observan en cada uno de los textos constitucionales estudiados, tanto en su literalidad normativa como en su aplicación en la práctica. Es por lo anterior que, si bien nosotros también "caemos en la tentación" de aludir especialmente a los aspectos divergentes entre los diferentes textos componedores del periodo, creemos que "nos libramos del mal» de obviar las relaciones básicas, estructurales, que dotan de unidad a un sentir moderantista del que podemos predicar -admitiendo los precedentes del Estatuto Real y la influencia reconocida sobre todo, de la Carta francesa de 1830-, que supone una corriente constitucional en España que -exceptuando la Constitución democrática de 1869 y el proyecto federal de 1873-, volverá a renacer en la Constitución canovista de 1876 y se mantendrá "velis nolis" hasta 1931, constituyéndose así en un elemento esencial para entender nuestra historia constitucional. 
Title:

"The influence of french constitutionalism on the phase of spanish constitutional reaffirmation (1837-1845)"

\title{
Summmary:
}

1.- INTRODUCTION. 2. THE CONSTITUTION OF THE SPANISH MONARCHY OF JUNE 18, 1837. 2.1.- Introduction. dogmatic part.- 2.2.Institutional organization. 2.2.1.- Executive power.- 2.2.2.- Legislative power.- 3.- THE CONSTITUTION OF THE SPANISH MONARCHY OF MAY 23, 1845. - 3.1.- Introduction. dogmatic part.- 3.2.- Institutional organization. 3.2.1.- Executive power.- 3.2.2.- Legislative power. 4.- ATTEMPTS TO REFORM THE CONSTITUTION OF 1845. 4.1.The constitutional projects of Bravo Murillo and Roncali..- 4.2.- The constitution "non nata" of 1856, the complementary Act of 1856 and the reform law of 1857. 5.- CONCLUSIONS.

\section{Key words:}

Influence of French constitutionalism; the French constitutional charters of 1840 and 1830; historic constitutionalism in Spain; the Spanish constitution of 1837; the Spanish constitution of 1845; Reform projects of the Spanish constitution of 1845; constitutional projects of Bravo Murillo and Roncali; the constitution "non nata" of 1856; the complementary act of 1856; the reform law of 1857; doctrinarian liberalism; moderantism; shared sovereignty.

\begin{abstract}
:
The influence of French constitutionalism is evident in the period of constitutional reaffirmation in Spain during the reign of Isabel II. This moderantist constitutional phase is committed to the "theory of the internal constitution" and takes as its point of departure the historical recognition of two basic principles that articulate (except for the democratic constitution of 1869 and the federal project of 1873) the Spanish constitutional and political reality: the Monarchy and Parliament. The shared sovereignty of the King and Parliament, together with a regime of collaboration between the powers arises from this reality. The French moderantism of the Charters of 1814 and 1830 is reflected in our Isabelline texts and the attempts at reform of the Constitution of 1845 . The Constitutions of 1837 and 1845 break with the revolutionary liberalism of Cadiz (thus the Constitution of 1837) and they later accommodate it to a doctrinarian and transactional liberalism that will receive the Eu-
\end{abstract}


ropean moderantist current, as can be observed in the 1845 text. As to the dogmatic context, for the first time in Spain a systemization of rights appears, postponing its development to the ordinary legislator. The shared sovereignty between the King and Parliament is the basic concept in order to understand the moderantism that can be appreciated in the Spanish texts of 1837 and 1845, as well as the French text of 1830. In contrast to the monocameralism of radical liberalism, a perfect bicameralism is consolidated between the lower house elected by universal suffrage and a Senate which acts as a moderator, not only due to its composition but also because it enjoys some competences similar to the elective House. Equally and omitting the first revolutionary liberalism, the rigid separation of powers gives way to a collaboration between them - appointment by the King of ministers who enjoy parliamentary support; the dissolution of Parliament by the King in the face of possible confrontation with the Government; compatibility of a ministerial post with a parliamentary mandate, fostering the powers of the Crown whose presence in the legislative context is quite intense, thus confirming a parliamentary regime whose precedents can be found while the Royal Statute in Spain and the Charter of 1814 in France were in force. 